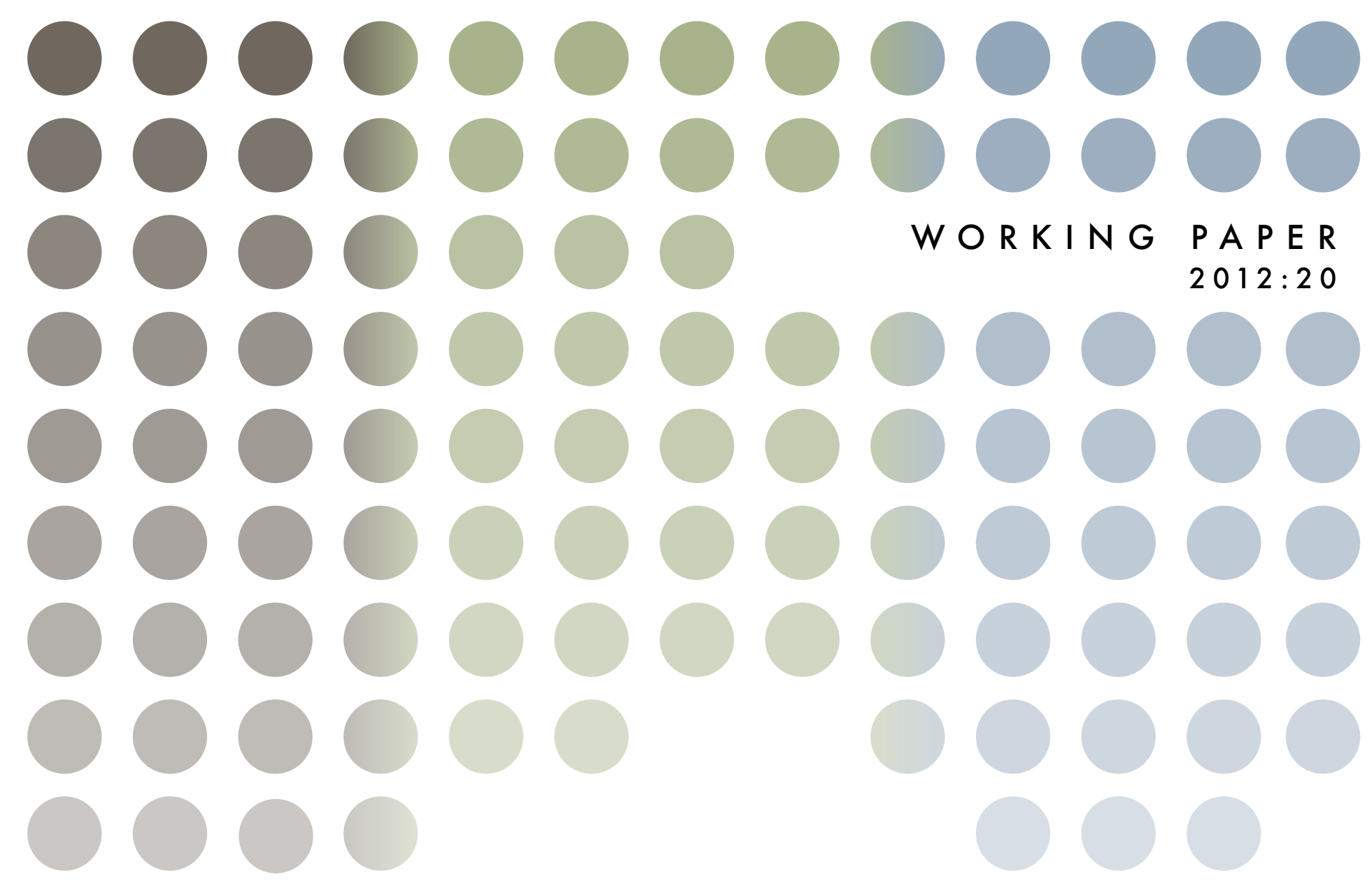

\title{
Does Academic Entrepreneurship Pay?
}

Pontus Braunerhjelm, Anders Broström and Thomas Åstebro

SWEDISH ENTREPRENEURSHIP FORUM 


\section{Working Papers Series from Swedish Entrepreneurship Forum}

In 2009 Swedish Entrepreneurship Forum started publishing a new series of Working Papers. These are available for download on www.entreprenorskapsforum.se, and are part of our ambition to make quality research available to a wider audience, not only within the academic world.

Scholars from different disciplines are invited to publish academic work with the common denominator that the work has policy relevance within the field of entrepreneurship, innovation and SMEs.

The working papers published in this series have all been discussed at academic seminars at the research institution of the author.

\section{ABOUT SWEDISH ENTREPRENEURSHIP FORUM}

Swedish Entrepreneurship Forum is the leading Swedish network organization for generating and transferring policy relevant research in the field of entrepreneurship and small enterprise development.

Swedish Entrepreneurship Forum is a network organization with the aim

- to serve as a bridge between the small business research community and all agents active in development of new and small enterprises.

- to initiate and disseminate research relevant to policy in the fields of entrepreneurship, innovation and SME.

- to offer entrepreneurship researchers a forum for idea sharing, to build national and international networks in the field and to bridge the gap between research and practical application.

Find out more on www.entreprenorskapsforum.se 


\title{
Does Academic Entrepreneurship Pay?
}

\author{
Pontus Braunerhjelm* \\ Anders Broström** \\ Thomas Åstebro***
}

Date of this version: November 23, 2012

\begin{abstract}
Various policies have been devised to stimulate the creation of spin-offs from universities by academics. But we still do not know whether it is privately beneficial for academics to start new businesses. To address this question we compile total earnings for the universe of 478 individuals aged 60 or less working at Swedish universities who quit to become

full-time entrepreneurs between 1999 and 2008. Using tax filings we record all possible earnings including wages, business income, dividends and capital gains. There are very few full-time academic entrepreneurs. Earnings are similar before and after becoming an entrepreneur and dividends and capital gains are inconsequential. But the income risk is more than three times higher in entrepreneurship. Entrepreneurship for academics appears a gradual process and quite episodic. Little explains entrepreneurial earnings except prior wage and forming a sole proprietorship.
\end{abstract}

JEL codes: : O32, J39, J62, M13.

Keywords: academic entrepreneurship, earnings, Sweden

* Swedish Entrepreneurship Forum and

Department of Industrial Economics and Management, Royal Institute of Technology. E-mail: pontus.braunerhjelm@entreprenorskapsforum.se

** Department of Industrial Economics and Management, CESIS, Royal Institute of Technology

*** Department of Strategy, HEC Paris

Acknowledgments: This study was undertaken as part of the project "Entrepreneurship, Industrial Development and Growth" jointly organized by the Research Institute of Industrial Economics (IFN) and Swedish Entrepreneurship Forum in Stockholm, Sweden. Financial support from the Torsten and Ragnar Söderberg Foundations is gratefully acknowledged. We thank Dina Neiman, Magnus Henrekson and the participants at a CIRCLE seminar and in the June 2011 IFN/Swedish Entrepreneurship Forum Conference Entrepreneurship, Industrial Development and Growth for helpful comments and suggestions. 


\section{Introduction}

Various policies have been devised to stimulate the creation of spinoffs from universities by academics, such as the Bayh-Dole act in the U.S., the Law on University Patenting in Denmark and similar changes in employment legislation in Germany, Norway, Austria and Finland to name a few (Åstebro and Bazzazian, 2011). Universities have also dramatically changed their policies, behavior and cultures over the past thirty years in order to promote the creation of more university spinoffs (Åstebro and Bazzazian, 2011). But we still do not know whether it is privately beneficial for academics to start new businesses.

We care about the private returns to entrepreneurship because we believe that money is an important motivator for employment choices. ${ }^{1}$ Knowing this simple number might also motivate policy in different ways. If, as for R\&D (Mansfield et al., 1977), the social returns are considerably higher than the private returns, there is an important argument for why university spinoffs should be actively stimulated. In particular, $f$ the private returns are negative but social returns are clearly positive there is an interesting conundrum. From a public perspective such activities are gainful and should be stimulated. But from a private perspective they are wasteful and should be discouraged. As the public gains on private but wasteful activities it constitutes a market failure and the academic entrepreneur may therefore require subsidies. To provide a starting point for analysis along these lines, we explore the private rates of return of academic entrepreneurs along with other features associated with their spells of entrepreneurship.

For most startups the private return to entrepreneurship is negative (Hamilton, 2000). The exception seems to be private returns to entrepreneurship for recent university graduates in sciences and engineering, which have been shown to be either positive or not significantly different from staying/becoming employed (Gort and Lee, 2007). It is an ongoing discussion whether one should focus the analysis on all entrepreneurs or whether some select group is preferable (e.g. Busenitz et al., 2003; Carter, 2011; Davidsson, 2005; Shane and Venkatamaran, 2000). Linked to this is the argument whether studying entrepreneurship should not include "self-employment," because it tilts the study of entrepreneurs towards low-income earners (e.g. Davidsson, 2005). Instead it is claimed that one should focus on understanding high-growth or high-tech ventures, or some other fraction of all entrepreneurs which are more likely to create employment, innovation and growth (Henrekson and Johansson, 2010). Most studies of the returns to entrepreneurship do however involve representative samples; these will be dominated by low-income earners (Hamilton, 2000). ${ }^{2}$

In this paper we concern ourselves with the returns to full-time academic entrepreneurship in Sweden. We chose this sample for several reasons. First, the creation of spinoffs from university research has increased dramatically since the early 1980s (Mowery et al., 2004). University spinoffs have been considered an important phenomenon and many studies have examined them (Shane, 2004; Rothaermel et al., 2007; Djokovic and Souitaris 2008; Åstebro and Bazzazian, 2011). Second, while university spinoffs have been studied at length, we still do not know very much about how much money academic entrepreneurs make. To our knowledge there is only one prior study on the topic (Åstebro et al., 2012). Third, we focus on Sweden because both employment and tax records in this country are exceptionally detailed and will allow us to capture returns previously unrecorded. We discuss the extent to which the Swedish data are representative of common trends. Finally, this sample of university spinoffs will represent mostly high-tech (knowledge- 
based) businesses, which is of greater economic importance than general self-employment (Sanandaji and Leeson, 2013).

University spinoffs represent a very small fraction of all startups. In the current analysis on how much money academic entrepreneurs make we compile the universe of 478 individuals working at Swedish universities in science, engineering and medicine who quit to become full-time entrepreneurs between 1999 and 2008. ${ }^{3}$ The Swedish data are unique in their comprehensiveness and detail. Through tax filings we collate wages, business income, dividends and capital gains (losses). To our knowledge this is the first study on the returns to entrepreneurship which includes capital gains specific to the venture. ${ }^{4}$

The average annual earnings as academics prior to leaving were SEK 397,000 and they were SEK 450,000 after becoming entrepreneurs. On average these earn SEK 50,000 (approximately $\$ 8,500$ ) more per year as entrepreneurs. However, when controlling for year dummies this difference becomes insignificant. The difference in log (percentage) earnings is negative and significant, but disappears after controlling for covariates. The Swedish data thus indicates that academic entrepreneurs on average do not make less than they would if staying employed at their university. However, they do take on substantially more risk: the standard deviation of earnings is more than three times larger after becoming an entrepreneur. This result is similar to those obtained by Åstebro et al. (2012) for U.S. academics and by all other studies showing that entrepreneurs take on too much risk in relation to the returns they obtain (e.g. Moskowitz and VissingJorgensen, 2002). This result poses follow-on questions. One might for example worry that the estimate of entrepreneurial earnings are not measuring all economic benefits from becoming an entrepreneur, in particular those not reported to tax authorities. 5 It seems however unlikely that academics would leave a steady and reasonably well paying job for another with highly uncertain rewards for the purpose of tax arbitrage. Swedish academics have plenty of time to operate small consulting businesses earning a part-time side income into which they both can shift some private consumption to pre-tax expenses and enjoy lower tax rates thus increasing disposable income as an academic. 6 The opportunity to reduce taxes is thus already present for Swedish academics without needing to become a full-time entrepreneur. Another follow-on question arising is whether there are potential non-monetary benefits that cause these individuals to leave their full-time employment to become entrepreneurs. We leave for future research to address this question.

\section{The Returns to Academic Entrepreneurship}

Raw data indicates that entrepreneurial incomes in general have been declining in comparison to wages. ${ }^{7}$ Parker (2004) summarizes the evidence from a number of studies and report relative earnings for U.S. entrepreneurs to be 48 percent from 1951-1954 and 23 percent from 1975-1979. By 1980-1984, earnings dropped to -10 percent, and then fell to -20 percent from 1985-1988. There has been a similar drop in relative earnings for entrepreneurs in the U.K. Relative earnings declined sharply from a peak of 90 percent in 1979 to approximately 35 percent in 1993 (Robson, 1997). ${ }^{8}$ By 2005 the mean annual earnings were almost identical, while the median earnings for self-employed were clearly below that of wage workers: $£ 12,948$ annually for entrepreneurs versus $£ 17,316$ annually for employees (Blanchflower and Shadfordth, 
2007). These numbers are informative but earnings must be analyzed by comparing similar individuals to avoid biased results. For this we turn to regression-based approaches.

Hamilton (2000) offers an early, careful study of the returns of entrepreneurship. The main analysis is in the form of cross-sectional Ordinary Least Squares (OLS) and quantile regressions of earnings-tenure functions of the form

$$
y_{i j t}=X_{i t} \beta_{j}+f_{j}\left(E X P R_{i j t}\right)+e_{i j t}
$$

where $y_{i j t}$ is the hourly earnings of individual $i$ in sector $j$ (wage, self-employment) at time $t, X$ is a vector of observed individual productivity characteristics such as education, EXPR is a vector of experience and tenure variables, and $e$ is a sector-specific random error term. The function $f($.$) relates to a sector-specific earnings-$ function.

One of the main contributions of Hamilton's paper to the discussion of the magnitude of entrepreneurial returns was to use three alternative measures of self-employment earnings and to show that results were, for the most part, qualitatively similar across all three measures: net profits, draw (wages) and equity adjusted draw (EAD). ${ }^{9}$ He found that both net profit and draw were less for all entrepreneurs compared to wage workers' earnings at all points of the distribution. For EAD earnings grew larger for entrepreneurs at the top $25^{\text {th }}$ percentile. The earnings distributions had much higher variance (standard deviation between 2 and 3.6 times greater) and a higher positive skew (longer upper tail) for entrepreneurs than for employees. For example, approximately 13 percent of entrepreneurs earned more than $\$ 20$ per hour when the EAD was used, compared to only 4.2 percent of employees. The conclusion that most workers earn more than entrepreneurs did not change when using multivariate regression. Hamilton's work has since been updated by several studies using self-employment data (Kawaguchi, 2003; Hartog et al., 2010; Tergiman, 2011). In general these studies indicate that the returns to self-employment are negative.

The returns to high-tech entrepreneurs might however be different than for self-employed. Relating this study to the returns of high-tech entrepreneurs seems appropriate since many university-employed academics in science, engineering and medicine who become entrepreneurs are likely to use their knowledge from their employment at the university to their startup, and these ideas might most often be qualified as high-tech (or at least knowledge-based.) High-tech entrepreneurs might on average be more highly educated than self-employed and we know that the returns to entrepreneurship increases considerably with education (Hartog et al., 2010; van der Sluis et al, 2008). Further, high-tech entrepreneurs might have higher opportunity cost having greater employment opportunities than others. This would tend to increase the average returns among those that choose to become entrepreneurs. Finally, high-tech entrepreneurs might have better ideas for new and disruptive businesses based on patents than typical businesses started by self-employed.

Data seems to agree with the conjecture that the returns to high-tech entrepreneurs are higher than the returns to self-employed (Gort and Lee, 2007). Braguinsky et al. (2013) further identify occupations and jobs that require especially intensive use of technical knowledge acquired through formal education and show that entrepreneurship generates considerable higher conditional mean and median pecuniary returns as compared to paid work in such jobs. In contrast, among scientists and engineers whose business ventures 
are not related to their education, the entrepreneurial earnings differential is negative, in line with findings in the previous literature. The positive earnings differential in education-intensive occupations increases with tenure in business, but declines with age.

While the expected return might be higher for high-tech entrepreneurs than self-employed there is another important feature of the returns distribution for this select sample of entrepreneurs. The distribution is highly skew (Giuri et al., 2007; Hall et al., 2005; Harhoff et al., 1999; Schankerman and Pakes, 1986; Schankerman, 1998; Scherer and Harhoff, 2000; Åstebro, 2003; Thursby and Thursby, 2007). For example, the Research Corporation (RC) which functioned as an intermediary between U.S. universities and buyers of intellectual property, accepted at least 9,000 disclosures and patented approximately 980 inventions sourced from U.S. universities between 1945 and 1985, but RC's top five inventions still represented as much as 98 percent of its yearly royalty income during this period (Mowery et al., 2004, Table 4.1).

In a previous attempt examining how much money academic founders of university spinoffs earn from creating their businesses (Åstebro et al., 2012), though not including capital gains, the earnings of entrepreneurs who were previously employed in academia in Science and Engineering are compared to their peers staying in academia. ${ }^{10}$ Raw data reveal that entrepreneurs receive sharply higher compensation than those which stay in academia. The gap between earnings by entrepreneurs and their peers in academia is lower for top-rated universities. This is probably because scientists at top-rated universities earn more than peers at other universities. Also, the pre-move earnings of former university employees who leave academia to launch their own businesses are much lower than earnings of those who stay in academia. This may indicate that university spinoffs may actually be driven by less productive scientists, at least less productive as members of the academic community. Of course, other factors also play a role and to control for these factors the authors use regression analysis.

The above study estimated Mincer-type regressions models of the kind reported in equation (1), except that they pool observations across university-employed academics and those who left universities to start a business. When controlling for everything observable the mean difference in earnings is not economically relevant. This is a surprising finding. One would expect there to be a premium to entrepreneurship given the rather clear evidence that there is a preference for doing science among U.S. academics (Stern, 2004; Roach and Sauermann, 2010). University quality has a positive and convex effect on wages. However, for entrepreneurial earnings the university quality has a positive impact only for the top 10 research universities in the U.S.

\section{Swedish Academic Entrepreneurship - Some Background Facts}

We start this section with some general observations concerning the settings in which Swedish universities operate, reflections on the specifics of the Swedish academic labor market, the tradition and rate of university-industry collaboration and academic entrepreneurship, and, finally, the tax environment for Swedish entrepreneurs. 


\section{STRUCTURE, INSTITUTIONS AND ATTITUDES}

The Swedish university system is characterized by considerably smaller size, less variety, and a substantially smaller share of private universities than in the U.S. A major change in the Swedish higher education system was its spatial decentralization with a major expansion of university education in 15 new institutions starting in $1987 .{ }^{11}$ These new institutions started as "community colleges" with shorter degree programs with vocational orientation in locations where there was no prior university, partly for regional employment purposes as shown by Andersson et al. (2004; 2009). They also provide evidence that this policy experiment has substantially increased patenting activity and productivity growth in the municipalities where the new institutions were located, and as well led to an increase in aggregate creativity and output in Sweden. With the signing of the "Bologna declaration" in 1999 these colleges drastically increased their volumes in international master's programs as education was free to international students, while lagging behind the established universities in research funding. A case example is given in Box 1.

Box 1. The Case of University College Halmstad.

A small teachers' college was created in Halmstad in 1973 from which University College Halmstad was formed in 1983; it is one of the youngest universities in Sweden. In the mid-1980s it was focused on teacher's education and shorter degree programs. Not until 1997 was University College Halmstad granted the rights to employ Full Professors; prior to that the teaching staff had lower status positions. The first Ph.D. was conferred in 1999. In 2008, University College Halmstad had some 50 degree programs, 5,000 full-time (11,500 total) students, approximately 40 professors and a research budget of 88 MSEK ( 8 mill USD). Thus, it graduated students in numbers 55 percent of Chalmers University of Technology in Göteborg, one of the oldest institutions in the country, but had an R\&D budget only 6 percent to that of Chalmers.

The Swedish labor market has been among the most heavily regulated among the OECD-countries leading to comparably low mobility rates, although regulation has been relaxed over the last decade. ${ }^{12}$ This regulation of course also applies to universities. The combination of heavy regulation and being part of a higher education system owned by the state suggests low labor mobility. As a benchmark, the private sector average yearly mobility rate in Sweden was 12.5 percent during the period 1987-2005 (Andersson and Thulin, 2013). It was lower for Ph.D.'s, a bit less than 11 percent, and mobility can thus be expected to be lower for university employees. Younger scholars at universities are particularly often employed at temporary contracts while senior scholars more often are on permanent contracts (Swedish National Agency for Higher Education, 2010), not unlike the U.S. tenure system.

In 1993 the government decided to enlarge the role of the universities to include a "third mission" -- to better diffuse university-based research and to take a more active part in the process of commercialization. To "kick-start" this process the first private holding companies, seeded with governmental money, were installed at 11 universities in 1994-1995. ${ }^{13}$ Today 15 university-based holding companies are in place. More recently several Technology Transfer Offices (TTOs) have been created in order to further enhance commercialization. The creation of these offices lags behind the U.S. by roughly 15 years, where 
approximately 75 percent of all TTOs were created before 1995 (Thursby and Thursby, 2007). The success of the Swedish TTOs varies substantially across the universities, several of the TTOs performing quite poorly. ${ }^{14}$

Irrespective of recent changes in university behavior in Sweden, there has always been a fairly high degree of interaction between Swedish university researchers and industry. For example, the Community Innovation Survey repeatedly shows that Swedish firms collaborate with universities much more frequently than firms in almost any other European country (Broström, 2009). This can partly be traced to the so-called "Teacher's Exemption" allowing faculty at Swedish universities to own their ideas. This exemption is in contrast to the 1980 Bayh-Dole act in the U.S. stipulating that the university owns the outcomes of university-funded research. Swedish researchers have historically worked together with primarily larger, and to some extent smaller, private firms to obtain access to industry funding and private research facilities. In turn they could often transfer Ph.D. students to employment as well assign their patents to the collaborating firms (Goldfarb and Henrekson, 2003; Wahlbin and Wigren; 2007; Åstebro and Bazzazian, 2011). Thus, Valentin and Jensen (2007) report that among biotech firms specialized in drug discovery, Swedish firms have university coinventors on patent applications on average 43 percent of the time, while comparable Danish firms have university co-inventors on patent applications on average 22 percent of the time.

As a direct effect of the above frequent university-industry interactions, a possible explanation of the lack of university-owned patents in Sweden is the high rate by which businesses are assigned patents by academics (Lissoni et al. 2008). ${ }^{15}$ However, that does not mean that Swedish university researchers are lagging their U.S. counterparts. Rather, Swedish academics are more active at patenting their research than their U.S. counterparts. Computing the share of Professors that are stated as inventors on a patent (irrespective of who is the assignee), Lissoni et al. (2008) find approximately 6 percent in Sweden, while the comparable figure for the U.S. for the same period (1994-2001) is 4 percent (Thursby et al., 2009). ${ }^{16}$ Using an alternative sampling process Ejermo (2012) confirm that between 5-7 percent of Swedish academics patent.

Swedish academics further seem positively inclined towards the commercialization of research. There are, however, marked differences across universities (Braunerhjelm, 2007). These differences are primarily related to university culture and the extent to which universities are well connected to industry. ${ }^{17}$ In a national survey of academics, Wahlbin and Wigren (2007), found that the average rates of entrepreneurship varied by a factor of five across different educational institutions. It is rather interesting to note that three of the five highest rates of entrepreneurship were among the newly founded institutions: the university colleges of Kristianstad, Blekinge and Borås. Data further shows that the number of started firms were seven to eight times larger than the number of licenses sold in one year, which may reflect the rather large number of patents voluntarily assigned to firms by researchers without transfer of money. Swedish academics increase their engagement in startup activities with tenure as well with scientific reputation (Wahlbin and Wigren, 2007). This is no different than in the U.S. (Stuart and Ding, 2006).

Regarding the number of full-time academic entrepreneurs, we made an effort to compare the Swedish employment register data with the U.S. SESTAT data. From the U.S. we obtained an extract showing the proportion of doctorate recipients in the Sciences, Engineering and Medicine aged up to 75 working at universities and surveyed in 1993, 1995, 1997, 1999, 2003 and 2006 who were recorded as full-time ownerentrepreneurs in the next consecutive survey. The difference in the average percentage rate of owner- 
entrepreneurship between Sweden and the U.S. across comparable years is -24 percent. ${ }^{18}$ Swedish academics thus appear to be less ownership-entrepreneurial than their U.S. counterparts.

\section{TAXES}

While the attitudes of academics and labor laws appears associated with the entrepreneurial orientation of Swedish academics, the Swedish tax system is also likely to impact the rate of academic entrepreneurship. Sweden is well-known as a high-tax society with taxes in relation to GDP being 45.5 percent, while the corresponding figures are 24.8 percent and 33.8 percent for the U.S. and the OECD-average, respectively. ${ }^{19}$

In the early 1990s the Swedish tax system was thoroughly reformed and a dual system was imposed, implying that the tax system distinguished between labor income which is taxed at progressively higher rates, and capital income which is taxed at a lower proportional rate. Since then, several amendments have been made to the Swedish tax system, including introducing an earned income tax credit for labor income and a reduction of taxes for incorporated, private firms. ${ }^{20}$

More precisely, labor income is taxed at three different levels. ${ }^{21}$ At the municipal level a flat rate (varying across municipalities) averaging 31.6 percent is levied up to an income threshold of SEK 414,000 where after a 20 percent state tax is charged. Income above 587,000 SEK are subject to an additional five percent state tax.

Capital income was until 2006 with few exceptions taxed at a flat rate of 30 percent. Since then the tax rate on capital depends on the type of capital income. Income from interest is still taxed at 30 percent, as is capital income from listed companies. For unlisted shares the tax rate is 25 percent while closely held corporations falls under a different set of quite complex tax rules. ${ }^{22}$ For the latter, a shareholder specific dividend allowance is defined for active owners, taxed at 20 percent. Dividends in excess of this allowance are taxed as labor income. The dividend allowance has substantially increased since the legislation was introduced in 1991, the latest change occurring in 2006.

Finally, corporate income tax has been lowered from 28 percent to first 26.3 percent in 2009, and it will be further reduced to 22 percent in 2013. Dividends are distributed to owners from after-tax corporate profit, the recipient is then taxed, where the tax rate depends on characteristics of both the owner and the corporation. Consequently, the dividends are taxed twice. Labor income can as well be argued to be taxed twice: first by payroll taxes at the corporate level which only partly relate to social insurance systems and then by income tax faced by individuals. This double taxation of labor income is however not unique to Sweden; many of its fellow European countries have similar systems.

The dual tax system encourages tax arbitrage between different sources of income, particularly for highincome earners. By shifting income from wages to dividends an entrepreneur would experience a reduction in the overall tax burden by 25.4 percentage points (2011 rates), taking the social security contribution paid by the employer into account. Thus, there are strong monetary reasons for individuals in Sweden to set up a firm in order to reduce their tax load. Taxes on wages are further withdrawn at source making it difficult for a wage earner to avoid the wage tax. Regular wage earners in fact have little opportunity to reduce their tax rates beyond standard deductions. Income from secondary sources can however easily (and as permitted by 
law) be recorded as business earnings making many academics prone to start their own business in order to reduce their taxes on such income. This clearly affects the rate of business startups recorded by the Swedish tax authority and we have therefore made a deliberate decision to avoid studying businesses started by academics where the individual remains an employee of their university as many of these are started for tax arbitrage reasons. The level of taxes and the marginal tax rates over the last decade are shown in the Appendix.

In sum, since the early 1980 s there has been an important increase in the rate of university-originated startups by faculty both in Sweden and in the U.S., even though the institutional set-up partially differs. Researchers have studied this important phenomenon from many perspectives. Only one study so far has indicated the earnings difference between those employed in universities and those leaving universities to become entrepreneurs (in the U.S.). That study indicated a somewhat complex set of relationship where the raw data indicate a positive difference, but the marginal effect was not significantly different from zero.

\section{Data and Methodology}

DATA

The Swedish register on all employed individuals working in the country was matched with register data from their employers by their social security number. From this matched employer-employee data set we extracted all 19,171 individuals with a Ph.D. degree in Medicine, Natural Science or Engineering who at some point during 1999-2008 were employed at a Swedish university. ${ }^{23}$ In addition, we merged in annual data on research funding and staff at Swedish universities from the Swedish National Agency for Higher Education.

\section{VARIABLES}

Income. Data on annual income are collected from the Swedish tax register. Four different sources of income are considered: (1) wages; (2) earnings from business activities; (3) dividends from firms in which the individual is, or during the last five years was working in; and (4) gains or losses from the sale of stocks in such ventures (hereon "capital gains"). ${ }^{24}$ These are inflation-corrected with the consumer price index to the year 2008. Capital gains are likely truncated for firms started towards the end of the panel; selling the firm is only possible after some development. To proxy for the potential future sale value we collected data on both dividends and capital gains for all firms for the two years 2009 and 2010 and added them to year 2008 values.

Entrepreneurship. Statistics Sweden defines an individual as a full-time entrepreneur if she owns a registered sole proprietorship or closely held corporation in a given year and her total income from this company (labor and capital income) is 1.6 times greater than labor income from employment in the single next greatest source of labor income. The adjustment with 1.6 is based on a separate labor survey performed by Statistics Sweden, which suggests that entrepreneurs work 1.6 more hours than employed for every krona/dollar earned. 
Using this definition we extracted 278 individuals leaving Swedish universities to become entrepreneurs during 1999-2008. To augment the study with more observations we consider as entrepreneurs those individuals who leave a position in academia to work full-time for a company with 10 or less employees founded in the year they left academia. Using this definition we extracted 200 additional entrepreneurs. Unfortunately, data on ownership is not complete for this latter group; such relationships can only be traced if the individual receives dividends and/or sells shares in the firm during the window of observation. We found 25 percent of the employees to be owners in this way and recoded these as owner-entrepreneurs. Several studies using the Danish matched employer-employee dataset have employed a similar definition of entrepreneurship (e.g. Nanda and Sorensen, 2010; Sorensen, 2007). Considerable regularities have been established using this definition of entrepreneurship and we consider us to be on safe ground using this additional sample. ${ }^{25}$ Summing these two groups, the rate of entrepreneurship varies between 0.4 percent and 1.4 percent per year, at an average 0.9 percent. In comparison with the mobility of Swedish Ph.D.'s in the private sector $(11 \%)$ this mobility rate is of course very limited.

We include socio-demographics of the individual, and data about the university at which the individual is (or recently was) employed and the region where the individual works (based on the address of the employer). Capturing the socio-demographic background of the individual we have unique data on their high-school grade point average (when available), and also more typical background characteristics such as their labor market history, education, country of birth, gender and age.

For labor market experience we use two measures. First, we measure the number of years since obtaining the Ph.D. ${ }^{26}$ Second, we include a measure of whether the individual had recent labor market experience prior to obtaining the Ph.D. We use dummy variables to control for sectoral differences in earning opportunities as entrepreneur. To capture the R\&D intensity of the university we use research funding per employee (in millions of Swedish kronor). We choose two variables to describe local opportunities. Sweden is divided into 72 pre-constructed functional labor market regions on the basis of commuting patterns. For each such region and year we approximate the size of the local labor market by the count of the number of individuals with tertiary education (bachelor degree or higher; in thousands). We further include a measure of the local rate of entry. This measure is deployed with a lag of two years to avoid simultaneity issues. Finally, for academics switching to entrepreneurship, we deploy dummies capturing three broad sector classifications; manufacturing, high-end services or low end services.

Data are organized as an unbalanced panel, entry and exit can occur any time. The average number of years of observation for an individual in the panel is 4.6 years; those who never become entrepreneurs are observed for an average 4.6 years, while those who become entrepreneurs are observed for an average 7.3 years, of which 5.2 years are as employed at university and 2.1 years are as entrepreneurs. We exclude individual-year observations whenever an entrepreneur switches back to the wage sector.

Table 1 reports variable definitions, means and standard deviations for two datasets. The first column includes all university-employed individuals with a Ph.D. degree in medicine, engineering, or natural sciences who never became entrepreneurs during 1999-2008. The second column those equally defined, but who quit their employment at the university and became full-time entrepreneurs some time during 1999-2008. The final column reports t-tests for significant differences between those becoming entrepreneurs and those never leaving academia. 
In a cross-sectional comparison Table 1 reveals that entrepreneurship does not pay. Those becoming entrepreneurs earn, on average, SEK 418,248 while those never becoming entrepreneurs on average earn SEK 443,994 . The difference is statistically significant $(t=-3.75, p<0.001)$. This difference may be due to pooling effects: the entrepreneurs may be different in some or several respects. We examine these differences in Table 1. Those becoming entrepreneurs are more likely to have an engineering degree, and are less likely to have either a medicine or a natural science degree than those staying academics. Those born in Sweden, the young, males, those with lower high-school grades, less experience, and with experience outside of academia prior to becoming university-employed are all more likely to become entrepreneurs. All these differences mean that comparing earnings between those not becoming entrepreneurs and those becoming entrepreneurs without taking into account that the two groups are composed of different people might be quite misleading.

Table 1 further reports that we have 40 percent year-observations in entrepreneurship, that only one out of ten firms are run as sole proprietorships (the rest are closely held corporations), and that a majority of the firms are started in high-end services (63\%), while 27 percent are started in the low-end service sector, and 10 percent in manufacturing. The fraction of sole proprietorships is considerably smaller than in a random sample of startups in Sweden (see Andersson and Klepper, this issue). 


\section{METHODOLOGY (OBS FELAKTIGA EKVATIONER I DETTA STYCKE)}

Estimating equations. The key issue with estimating an income equation for entrepreneurs is that the choice of entrepreneurship may be endogenous. It might be a function of expected returns as well as unobserved (for the econometrician) characteristics. To address this we use a diff-in-diff regression approach; we only analyze the difference in earnings for those that become entrepreneurs. The estimating equation is the earnings model

$$
\ln y i t=\alpha+\operatorname{Eit}(\beta+\delta \mathrm{Xit})+\theta i+\tau t+\varepsilon i t
$$

where $y_{\mathrm{it}}$ is annual earnings for individual $i$ in year $t, E_{\mathrm{it}}$ is employment status ( $=1$ if entrepreneur, $=0$ if employed in academia) in year $t, X_{\text {it }}$ is a vector of (potentially time-varying) covariates that may determine the returns to entrepreneurship, $\theta_{i}$ are person-fixed effects that do not vary over time, $\tau_{t}$ are time-fixed effects, and $\varepsilon_{i t}$ is an i.i.d. error term. We also run the equation taking the log of annual earnings. This alternative specification is useful for estimating the percentage change in earnings, while the base equation is useful for estimating the impact of becoming an entrepreneur on the earnings level. When estimating the log of earnings, observation with negative total earnings (12\%) are re-coded to earning one krona in order to compute the log.

We thus estimate the effect of the covariates on the difference in income between entrepreneurship and employment for a given individual. Identification is based on the individuals who are observed to change employment status once. The diff-in-diff approach controls for unobserved individual characteristics that do not change over time and thus eliminates bias originating in permanent disposition and inclination for entrepreneurial activity. It will not eliminate bias from unobserved characteristics that vary systematically with employment status over time, or from unobservable circumstances that stimulate an individual to become an entrepreneur at a particular point in time, such as the arrival of an idea, or the disagreement with a co-worker. We assume that these unobservable circumstances are random in the sense that they are not correlated with the variables in the equation.

A peculiar characteristic of the Swedish academic system is that Ph.D. students are employed by their university and are thus registered as wage earners. These face a different opportunity set than regular faculty members, leading Ph.D. students to be more likely to become entrepreneurs or take jobs in industry than faculty. We therefore exclude from analysis those that move to non-academic wage employment / entrepreneurship directly upon graduation.

A secondary set of analysis is performed distinguishing between those that become entrepreneurs and those who stay in academia. There is likely selection into entrepreneurship based both on observable as well as unobservable characteristics. This analysis is by no means necessary as selection on individual-fixed attributes in a non-issue in the above difference-in-difference analysis. To examine what we can tell about whom among all academics becomes an entrepreneur we estimate a panel-data logistic regression of the general form, 


$$
P\left(E_{i t}\right)=\alpha+\beta X_{i t}+\theta_{i}+\tau_{t}+\varepsilon_{i t}
$$

where notation is as before. The panel-logit model identifies who becomes an entrepreneur based on observable covariates $X_{i t}$.

Missing data. Data were missing for GPA for about 50 percent of the sample. While grades from secondary studies in Sweden after 1980 are reported without fail, data for other individuals have been collected in surveys reaching only a limited part of the population. Missing items were imputed three times assuming data were Missing At Random using a switching regression approach described in van Buuren et al. (1999), where missing data were randomly replaced conditional on observed data. We report coefficient estimates and standard errors computed over the three complete datasets.

\section{Results}

\section{DESCRIPTIVE STATISTICS}

We start the analysis with some descriptive statistics. Table 2 reports total earnings (the sum of wages, pretax business income, dividends and capital gains) for those which become entrepreneurs prior to and after becoming entrepreneurs. It is immediately apparent that total earnings decline sharply for the average academic once they become full-time entrepreneurs. The average pre-entrepreneurship earnings are SEK 397,307 while it increases to SEK 450,341 as an entrepreneur. The difference is statistically significant with $t=2.61, p<0.01$. The difference in total earnings between the year prior to and the first year as an entrepreneur is smaller. The former is SEK 367,886 and the latter SEK 395,349 and their difference is statistically insignificant. From these comparisons we can immediately draw the conclusion that academic entrepreneurship, on average, pays off moderately. However, those becoming full-time entrepreneurs also take on substantially more risk: the standard deviation of earnings is more than three times larger after becoming an entrepreneur.

That the earnings in the year prior to entrepreneurship are less than the average pre-entrepreneurship earnings cannot be due to pooling effects (that the least able are those that switch, for example). There are instead two other potential explanations. First, that the academics prior to switching experience a negative earnings shock, for example by having funding of "top-up" salary cut. Second, that this is the result of a gradual transition. Earnings in the year prior to entrepreneurship may not be a full year of wages if the individual switches to part-time entrepreneurship some time in that year but does not get registered as fulltime entrepreneur until the next year. (Recall that Statistics Sweden unfortunately do not record number of hours worked in a year, except on a smaller random sample.) We examine whether there is a negative earnings shock by differencing earnings two years and one year prior to becoming an entrepreneur. The difference is negative SEK 8,657 and statistically insignificant indicating that becoming an academic entrepreneurship on average is not associated with a prior negative earnings shock.

Table 2 also displays that entrepreneurs pay themselves a significant amount of salary, which is not unexpected since the reported average level of salary closely matches the level which entitles the individual 
to full access to the Swedish social insurance systems. Additional payroll fees above the entitlement level are simply a pure tax. Hence, beyond the entitlement level, it is more beneficial to extract earnings as dividends since such incomes are taxed at a lower rate than wages. Moreover, in order to enjoy the lower tax rate on dividends (30\% until 2005, 20\% thereafter) a business owner must pay himself some wages as a fraction of his total income.

Prior to becoming an entrepreneur the business income is small; mean SEK 8,038 (median SEK 25,000). This income might be generated from part-time consulting or similar activities. There are also both dividends and capital gains reported prior to becoming an entrepreneur, on average SEK 6,433 and 743 per year (median values of SEK 21,000 and 19,000). Only seven individuals have capital gains from entrepreneurship already as university employees, of whom three have annual capital gains above SEK 200,000. While small, these numbers indicate that there are some modest entrepreneurial activities before becoming a full-time entrepreneur for many. Indeed, one in four had some side income from business activities while employed at universities.

Notably, both the dividends and capital gains increase substantially when becoming an entrepreneur to SEK 73,028 and 4,753 (median values SEK 82,000 and 30,000), respectively. Nevertheless, the bulk of entrepreneurial earnings ( $61 \%$ at the mean but $99 \%$ at the median) are still from wages. The reason for that dividends and capital gains do not affect total earnings for most entrepreneurs (at the median) is because dividends and capital gains are substantially uneven and infrequent. Only eight individuals have capital gains from full-time entrepreneurship. Of these, only four year-observations (four different individuals) are higher than SEK 200,000.

Figure 1 illustrates the distribution of total earnings for three groups: the solid line represents those academics never becoming entrepreneurs, the dotted line the earnings during entrepreneurship, and the dashed line earnings prior to becoming an entrepreneur. The figure shows a shift to higher earnings after becoming an entrepreneur, and also higher earnings compared to those never becoming entrepreneurs. The entrepreneurial earnings distribution clearly has fatter tails, meaning greater risk. All three distributions (even those never becoming entrepreneurs) have a significant bump at the top representing capital gains.

A final piece of descriptive statistics covers the survival length of academic entrepreneurship. To illustrate this we plot a Kaplan-Meier survival graph in Figure 2. This graph represents the length of time which the individual remains an entrepreneur (not the survival of their business). The figure shows that many of the spells as entrepreneur are very short. More than 30 percent of the individuals exit from entrepreneurship within one year and over 60 percent within two years. Out of those leaving entrepreneurship within two years, fully 66 percent return to academia.

\section{REGRESSION RESULTS}

After presenting the descriptive data we move to regression analysis. The first column in Table 3 reports the baseline earnings regression which includes the entrepreneurship indicator and year dummies. The coefficient for switching to entrepreneurship is economically small (SEK 26,070) and statistically insignificant. The reason for the change in result from the descriptive data is the inclusion of the year dummies. It turns out that annual earnings have been increasing almost monotonically from 1999 to 2008 (at 2008 prices) 
reflecting a boom in the economy and that this increase is associated with becoming an entrepreneur purely for statistical reasons (the cumulative probability of something happening increases as time at risk increases). To illustrate this increase, we plot the estimated changes in average total earnings for each year between 1999 and 2008 in Figure 3 (obtained from the first regression in Table 3) as well the estimated earnings effect from switching to entrepreneurship. We checked whether the estimated earnings difference between entrepreneurship and wage work is increasing with time and found that it is not. The estimated zero gain to entrepreneurship is statistically the same across all years in the dataset.

The second column includes all covariates interacted with the entrepreneurship indicator (except the year dummies). The entrepreneurship indicator is still not strongly significant $(p=0.06)$, although the sign turns negative and the magnitude is twelve times as large as before (SEK -263,670.) Among the covariates, only one is significant. Operating as a sole proprietor reduces earnings by SEK 239,841 ( $t=-6.92, p<0.01)$ compared to entrepreneurship in closely held corporations. Note that entrepreneurs where business ownership is not recorded do not earn a different income than owner-entrepreneurs. Introducing the covariates does not markedly change the magnitudes or significance of the year dummies, indicating that "a rising tide lifts all boats." The third column reveals the percentage change in earnings from becoming an entrepreneur when controlling for year effects, estimated as $100 *[\exp (-0.256)-1]=-23$ percent. The reason for obtaining a negative base estimate compared to obtaining a positive before is that the log of earnings transforms down a proportionally larger group with extreme earnings among the entrepreneurs. The impact of this transformation is illustrated in Figure 4, which shows the distributions of the log of total earnings for the same three groups as in Figure 1.

The fourth column of Table 3 shows that the percentage change estimate in earnings does not vary much across different groups of entrepreneurs, and that the average effect across all entrepreneurs is not statistically significant. There are however three groups which have statistically different earnings among all entrepreneurs. Those born outside of Sweden and sole proprietors have significant lower percentage earnings, while those where ownership is not registered (employees in small startups) have significantly higher percentage earnings compared to their pre-entrepreneurship earnings.

As stated before there is no need to estimate or control for selection into entrepreneurship when running an earnings equation with individual fixed effects of the type described in Equation (1). However, we nevertheless move on to explore the reasons for why some academics become entrepreneurs in order to give an insight into their composition beyond what is reported in Table 1. For this purpose we expand the sample to all academics working in Medicine, Natural Sciences and Engineering between 1999 and 2008. Results of a panel-data logit model are presented in Table 4. Quite a few of the variables are correlated with who becomes an entrepreneur. At the individual level there are negative correlations with GPA, years of experience and with being born outside of Sweden. Males and those with non-academic experience are more likely to become entrepreneurs. Those who have an engineering degree are more likely to become an entrepreneur than those with a Ph.D. in medicine or the natural sciences. The higher the R\&D-intensity of the university the greater the likelihood of becoming an entrepreneur, while the greater the local entry rate the lower the probability of becoming an entrepreneur. ${ }^{27}$ When including lagged income the effect of grade point average drops out while other variables remain at around prior magnitudes. This indicates that prior earnings may indeed by a good proxy for (otherwise) unobserved ability, as traditionally assumed. Note that 
those who are less able, both in terms of GPA and prior wage, are more likely to become entrepreneurs. That is, there is negative selection into entrepreneurship in this dataset. The final variable added in the second column is the difference in earnings two years lagged versus one year lagged. This variable is not significant, confirming the prior t-test indicating no specific effect of a prior negative earnings shock upon entry.

\section{Summary and conclusions}

Various policies have been devised to stimulate the creation of spinoffs from universities by academics. But we still do not know whether it is privately beneficial for academics to start new businesses. To address this question we compile total earnings for the universe of 478 individuals aged 60 or less working at Swedish universities in Medicine, Natural Sciences or Engineering who quit to become full-time owner-entrepreneurs or employed in a small startup between 1999 and 2008. Approximately 0.9 percent of all academics become full-time entrepreneurs every year in Sweden. Earnings data include tax filings on wages, business income, dividends and capital gains. The average annual earnings as academics prior to leaving were SEK 397,000, while they were SEK 450,000 after leaving. This difference in earnings is a result of pooling effects over years with generally increasing earnings. When controlling for year dummies this difference instead becomes negative, but only marginally significant. The difference in log (percentage) earnings is negative and significant, but disappears after controlling for covariates. Very little explains the earnings difference. There is negative selection into entrepreneurship; those with lower pre-entry earnings are more likely to become entrepreneurs.

These are surprising findings. One would expect there to be a premium to entrepreneurship given the rather clear evidence that there is a preference for doing science (Stern, 2004; Roach and Sauermann, 2010.) In addition, the academics also take on substantially more risk: the standard deviation of earnings is more than three times larger after becoming an entrepreneur compared to before. The lack of a premium to compensate for this added income risk is yet another puzzle, although both results are consistent with several prior studies showing similar findings (summarized in Åstebro, 2012).

Both dividends and capital gains are inconsequential for total earnings except for a very small group of individuals. We found only four entrepreneurs (less than 1\%) obtaining capital gains higher than half the average pre-entrepreneurship earnings. Further, it appeared that entrepreneurship is a gradual process for many academics. At least one quarter of all academics who become full-time entrepreneurs already operated as part-time entrepreneurs while employed at their university. Finally, full-time academic entrepreneurship is very episodic. A large fraction, over 60 percent, quit full-time entrepreneurship within two years and 66 percent of those return to academia.

In conclusion, full-time entrepreneurship by former university-employed is not a frequent phenomenon. Neither does entrepreneurship appear to be very important for those that undertake it. Most of them glide into it gradually and very rapidly switch out of it. The gains from becoming an entrepreneur are equivalent to remaining at work at the university and entail much greater income risk. 
It seems that supporting this type of activity with public policies might not matter very much. Nevertheless, there is no reason to actively try to discourage the behavior. Even though there are large income risks involved, academics appear to easily switch out of the risky activity. The social rates of return to this activity could be large even though the private returns are here estimated to be close to nil. As such, it appears that academics should be left alone to do what they enjoy best. 


\section{References}

Ajayi-Obe, O., and S.C. Parker (2005), 'The Changing Nature of Work among the Self-Employed in the 1990s: Evidence from Britain', Journal of Labor Research, 26, 501-517.

Alstadsæter . A. and M. Jacob (2012), 'Income Shifting in Sweden. An Empirical Evaluation of the 3:12 rules', Report to the Expert Group on Public Economics 2012:4, Ministry of Finance, Stockholm.

Andersson, M. and S. Klepper (2013), 'Characteristics and Performance of New Firms and Spinoffs in Sweden', Industrial and Corporate Change, this issue.

Andersson, M. and P. Thulin (2013), 'Does Spatial Employment Density Spur Inter-Firm Job Switching?', Annals of Regional Science, forthcoming

Andersson, R., Quigley, J. and M. Wilhelmsson (2004), 'University Decentralization as regional Policy: the Swedish Experiment', Journal of Economic Geography, 4, 371-388.

Andersson, R., J. Quigley and M. Wilhelmsson (2009), 'Urbanization, Productivity and Innovation: Evidence from Investment in Higher Education', Journal of Urban Economics, 66, 2-15.

Åstebro, T. (2003), 'The Return to Independent Invention: Evidence of Unrealistic Optimism, Risk Seeking or Skewness Loving?', Economic Journal, 113, 226-239.

Åstebro T. (2012), 'Returns to Entrepreneurship', in D. Cummins (ed.), Handbook of Entrepreneurial Finance, Oxford University Press, pp. 45-108.

Åstebro T. and N. Bazzazian (2011), 'Universities, Entrepreneurship and Regional Economic Development', in M. Fritsch (ed.), Handbook of Research on Entrepreneurship and Regional Development. Edward Elgar: Cheltenham.

Åstebro, T., N. Bazzazian and S. Braguinsky (2012), 'Startups by Recent University Graduates and their Faculty - Implications for University Entrepreneurship Policy', Research Policy, 41, 663-677.

Åstebro, T., J. Chen and P. Thompson (2011), 'Stars and Misfits: Self-Employment and Labor Market Frictions', Management Science, 57, 1999-2017.

Berglann, H., E.R. Moen, K. Røed and J.F. Skogstrøm (2011), 'Entrepreneurship: Origins and returns', Labour Economics, 18, 180-93.

Blanchflower, D.G., and C. Shadfordth (2007), 'Entrepreneurship in the U.K.', Foundations and Trends in Entrepreneurship, 3, 257-364.

Braguinsky, S., S. Klepper and A. Ohyama. (2013), 'High Tech Entrepreneurship', Journal of Law and Economics, forthcoming.

Braunerhjelm, P. (2008), 'Regional Specialization and Universities: The New versus the Od', 
Industry and Innovation, 15, 253-275.

Braunerhjelm, P. (2007), ‘Academic Entrepreneurship. Social Norms, University Culture and Policies', Science and Public Policy, 34, 619-31.

Broström, A. (2009), Strategists and Academics: Essays on Interaction in R\&D. Doctoral thesis, KTH, TritaTEC-PHD 09:003.

Busenitz, L.W., G. Page West III, D. Shepherd, T. Nelson, G.N. Chandler, A. Zacharakis (2003), 'Entrepreneurship Research in Emergence: Past Trends and Future Directions', Journal of Management, 29, 285-308.

van Buuren, S., H.C. Boshuizen and D.L. Knook (1999), 'Multiple Imputation of Missing Blood Pressure Covariates in Survival Analysis', Statistics in Medicine, 18, 681-694.

Carter, S. (2011), 'The Rewards of Entrepreneurship: Exploring the Incomes, Wealth, and Economic WellBeing of Entrepreneurial Households', Entrepreneurship Theory and Practice, 35, 39-55.

Davidsson, P. (2005), Researching Entrepreneurship. Springer: New York.

Djokovic, D., and V. Souitaris (2008), 'Spinouts From Academic Institutions: a Literature Review with Suggestions for Further Research', Journal of Technology Transfer, 33, 225-247.

Edmark, K. and R. Gordon (2013), 'The Choice of Organizational Form by Closely-Held Firms in Sweden: Tax vs. Non-Tax Determinants', Industrial and corporate Change, this issue.

Ejermo, O. (2012), 'Patenting in Swedish Academia: Milieux, Career and Gender Effects', Working paper, Lund University.

Färnstrand Damsgaard, E. and M. Thursby, (2013), 'University Entrepreneurship and Professor Privilege', Industrial and Corporate Change, this issue

Giuri, P., M. Mariani, S. Brusoni, G. Crespi, D. Francoz, A. Gambardella, W. Garcia-Fontes, A. Geuna, R. Gonzales, D. Harhoff, K. Hoisl, C. Le Bas, A. Luzzi, L. Magazzini, L. Nesta, O. Nomaleri, N. Palomeras, P. Patel, M. Romanelli, and B. Verspagen (2007), 'Inventors and invention processes in Europe: Results from the PatVal-EU survey', Research Policy, 36, 1107-1127.

Goldfarb, B. and M. Henrekson (2003), 'Bottom-Up versus Top-Down Policies towards the Commercialization of University Intellectual Property', Research Policy, 32, 639-658.

Gort, M. and S. H. Lee (2007), The Rewards to Entrepreneurship. Buffalo: State University of New York.

Hall, B. H., A. Jaffe and M. Trajtenberg (2005), 'Market Value and Patent Citations', Rand Journal of Economics, 36, 16-38.

Hamilton, B., (2000), 'Does Entrepreneurship Pay? An Empirical Analysis of the Returns to Self-Employment', Journal of Political Economy, 108, 604-631. 
Hansson, Å., (2008), Skatter, entreprenörskap och nyföretagande, Report No. 12 to Swedish Globalization Council, Regeringskansliet: Stockholm.

Harhoff, D., F. Narin, F. M. Scherer and K. Vopel (1999), 'Citation Frequency and the Value of Patented Inventions', Review of Economics and Statistics, 81, 511-515.

Hartog, J., C. M. Van Praag and J. Van der Sluis (2010), 'If You are So Smart Why are You not an Entrepreneur? Returns to Cognitive and Social Ability: Entrepreneurs Versus Employees', Journal of Management Strategy, 19, 947-989.

Henrekson, M. and D. Johansson (2010), 'Gazelles as Job Creators: A Survey and Interpretation of the Evidence', Small Business Economics, 35, 227-44.

Iversen, E. J., M. Gulbrandsen and A. Klitkou (2007), 'A Baseline for the Impact of Academic Patenting Legislation in Norway', Scientometrics, 70 (2), 393-414.

Kawaguchi, D. (2003), 'Human Capital Accumulation of Salaried and Self-employed Workers', Labour Economics, 10, 55-71.

Lazear, E.P. and K. Shaw (2007), 'Wage Structure, Raises and Mobility: International Comparisons of the Structure and Wages Within and Across Firms', NBER working paper 13654, Cambridge, MA.

Lissoni, F., P. Llerena, M. McKelvey and B. Sanditov (2008), 'Academic Patenting in Europe: New Evidence from the KEINS Database', Research Evaluation, 17, 87-102.

Mansfield, E., J. Rapoport, A. Romeo, S. Wagner and G. Beardsley (1977). 'Social and Private Rates of Return from Industrial Innovations', The Quarterly Journal of Economics, 91, 221-240.

Mowery, D.C., R.R. Nelson, B.N. Sampat and A.A. Zeidonis (2004). Ivory Tower and Industrial Innovation. Stanford University Press: Stanford.

Meyer, M. (2003), 'Academic Patents as an Indicator of Useful Research? A New Approach to Measure Academic Inventiveness', Research Evaluation, 12, 17-27.

Moskowitz, T. J., and A. Vissing-Jorgensen (2002), 'The returns to Entrepreneurial Investment: A private Equity Premium Puzzle?', American Economic Review, 92, 745-778.

Nanda, R . and J.B. Sorensen (2010), 'Workplace Peers and Entrepreneurship', Management Science, 56, 1116-1126.

OECD, www.oecd.org/newsroom/taxrevenuesrisingslowlyacrosstheoecd.htm.

OECD (1986), Employment Outlook. Organisation for Economic Co-operation and Development: Paris.

Parker, S.C. (2004), The Economics of Self-Employment and Entrepreneurship. Cambridge University Press: Cambridge.

Parker, S.C. (2009), The Economics of Entrepreneurship. Cambridge University Press: Cambridge. 
Roach, M. and H. Sauermann (2010), 'A Taste for Science? PhD Scientists' Academic Orientation and Selfselection into Research Careers in Industry', Research Policy, 39, 422-434.

Robson, M.T. (1997), 'The Relative Earnings from Self and Paid Employment: A time-series Analysis for the UK', Scottish Journal of Political Economy, 44, 502-518.

Rothermael, F. T., S.D. Agung and L. Jian (2007), 'University Entrepreneurship: A Taxonomy of the Literature', Industrial and Corporate Change, 16, 691-792.

Sanandaji, T., and P. T. Leeson (2013), 'Billionaires', Industrial and Corporate Change, this issue.

Schankerman, M. (1998), 'How Valuable is Patent Protection? Estimates by Technology Field', Rand Journal of Economics, 29, 77-107.

Schankerman, M., and A. Pakes (1986), 'Estimates of the Value of Patent Rights in the European-Countries During the Post-1950 Period', Economic Journal, 96, 1052-1076.

Scherer, F. M., and D. Harhoff (2000), 'Technology Policy for a World of Skew-Distributed Outcomes', Research Policy, 29, 559-566.

Shane, S. (2004), Academic Entrepreneurship: University Spinnoffs and Wealth Creation. Edward Elgar: Cheltenham.

Shane, S. and S. Venkataraman (2000), 'The Promise of Entrepreneurship as a Field of Research', Academy of Management Review, 25, 217-226.

Skedinger, P. (2009), 'Sweden: A minimum Wage Model in Need of Modification?', in D. Vaughan-Whitehead (ed.), The Minimum Wage Revisited in the Enlarged EU. Palgrave: London

Sorensen, J.B. (2007), 'Bureaucracy and Entrepreneurship: Workplace Effects on Entrepreneurial Entry', Administrative Science Quarterly, 52, 387-412.

Stern, S. (2004), 'Do Scientists Pay to Be Scientists?', Management science, 50, 835-853.

Stuart, T. and W. Ding (2006), 'When Do Scientists Become Entrepreneurs? The Social

Structural Antecedents of Commercial Activity in the Academic Life Sciences', American Journal of Sociology, $112,97-144$

Swedish National Agency for Higher Education (2010) Swedish universities \&

university colleges - Short version of annual report, 2010 13:R.

Taylor, M.P. (1996), 'Earnings, Independence or Unemployment: Why become Self-employed?', Oxford Bulletin of Economics and Statistics, 58, 253-266.

Tergiman, C. (2011), 'Entrepreneurship does Pay', Working paper, available from ssrn.com (downloaded September 11, 2011.) 
Thursby, J.G., and M.C. Thursby (2007), 'University licensing', Oxford Review of Economic Policy, 23, 620639.

Thursby, J., A.W. Fuller and M. Thursby (2009), 'US Faculty Patenting: Inside and Outside the University', Research Policy, 38, 14-25.

Valentin, F. and R.L. Jensen (2007), 'Effects on Academia-Industry Collaboration of Extending University Property Rights', Journal of Technology Transfer, 32, 251-276.

Van der Sluis, J., M. van Praag and W. Vijverberg (2008), 'Education and Entrepreneurship Selection and Performance: A Review of the Literature', Journal of Economic Surveys, 22, 795-841.

Wahlbin, C. and C. Wigren (2007), Samverkan i det akademiska vardagslivet: En undersökning av svenska forskare och lärares deltagande i och inställning till samverkan med det omgivande samhället. Verket för näringslivsutveckling (NUTEK): Stockholm.

\footnotetext{
${ }^{1}$ With the "returns to entrepreneurship" we mean the financial returns to an individual from the choice to be or become an entrepreneur in comparison to staying employed. The topic was most recently reviewed by Åstebro (2012), Carter (2011), Parker (2009), van Praag and Versloot (2007) and Parker (2004).

${ }^{2}$ Note that self-employed individuals running businesses which employ others are almost always included in representative samples, but since few entrepreneurs are successful enough to employ anyone, entrepreneurs employing others represent a minority. For a separation of earnings between these groups, see, for example, Ajayi-Obe and Parker (2005) and Berglann et al. (2011).

${ }^{3}$ See also Åstebro et al. (2012).

${ }^{4}$ Berglann et al. (2011) include income from all types of capital (public and private stocks, bonds, savings, etc) and show that such capital income represents approximately $50 \%$ of total annual earnings for entrepreneurs in limited liability companies. Capital income from the business itself is however not separately reported. Hamilton (2000) reports the equity adjusted draw; the sum of
} 
the draw (wages) and the change in equity between two annual reports (available for approximately $25 \%$ of the sample) for two years; 1984 and 1985, limiting the ability to compute cumulated capital gains.

${ }^{5}$ See Edmark and Gordon (2013, this issue), for a review of Swedish taxes on entrepreneurship.

${ }^{6}$ As shown by Hansson (2008), the propensity to start a part-time business is highest among those in the higher income brackets.

${ }^{7}$ This section contains edited extracts from Åstebro (2012).

${ }^{8}$ Robson (1997) used aggregate national accounts. Using instead the British household panel data, Taylor (1996) report that by 1991 the self-employed on average earned less the employed ( $£ 8.20$ versus $£ 9.71$ per hour.)

${ }^{9}$ Draw is the wage equivalent, or the consumption the business generates for its owner. EAD represents draw plus adjusted change in business equity over $[t, t+1]$.

${ }^{10}$ Data covers college-educated U.S. scientists and engineers (Computer and mathematical sciences, Life sciences, Physical sciences, Social sciences and Engineering).

${ }^{11}$ Andersson et al. $(2004 ; 2009)$ report that as of 1977 there were only six universities and five other educational institutions operating in Sweden, By 1987 this number had grown to 36 located in 26 different municipalities.

${ }^{12}$ Mobility rates vary substantially across countries from low in Norway, Sweden, and Finland, to high in France, Italy and the U.S. (Lazear and Shaw, 2007). In Sweden there are strict rules regarding the order of lay-offs (based on a last-in first-out principle), the legally accepted reasons for lay-offs, and quite prohibitive liabilities for obstructing those rules. As a result the Swedish labor market was characterized by low mobility and considerable barriers for marginal groups to enter (Skedinger 2009). Over the last decade the labor protection rules have however been reformed. In particular, temporary employment contracts, allowing labor to be hired for 24 months, have been allowed since 2006. The result is a dual labor market, with considerable greater mobility and flexibility, but only for those with time limited contracts (approximately 15-16 percent of the labor force). The remaining part of the labor force still falls under the old rules. Nevertheless, lack of work, e.g. due to a downturn in the business cycle, has always been a legally accepted reason to fire. And smaller firms (less than 10 employees) are exempted from some of the stricter labor protection rules.

${ }^{13}$ Those were (their endowments in parenthesis, million SEK): Uppsala university (SEK 9M), Lund University (SEK10M), University of Gothenburg (SEK 6M), Stockholm University (SEK5M), Umeå University (SEK 5M), Linköping University (SEK 5M), Karolinska institutet (SEK 5M), The Royal Institute of Technology (SEK 7M), Luleå Technical University (SEK 4M), Swedish University of Agricultural Sciences (SEK 4M) and Halmstad University (SEK 5M). Their initial governmental endowments were thus rather modest but have since then increased through joint operations with other private and public agents. Since then another four regional universities have been added to the list. See http://www.hsv.se/download/18.5b73fe55111705b51fd80004652/0733R uppdrag kontakter.pdf and various documents at the Swedish National Agency for Higher Education (www.hsv.se). 
${ }^{14}$ See the analyses in Braunerhjelm $(2007,2008)$ based on a survey sent out by the Swedish National Audit Office to scholars at all Swedish universities in the natural sciences, medicine and engineering departments.

${ }^{15}$ The fractions are similar in France and Italy. In France, and to a lesser extent in Italy, a sizeable share of academic patents is also owned by large governmental research organizations, reflecting the importance of these actors in these countries (Lissoni et al. 2008).

${ }^{16}$ Overall, Italian academics represent 3 percent of European Patent Office patents awarded to Italians (Balconi, Breschi, and Lissoni, 2004). In Finland academics represent 8 percent of all patent assignees (Meyer, 2003) and in Norway they represent almost 10 percent of all assignees (Iversen et al., 2007).

${ }^{17}$ The old Swedish universities are located within or close to large and medium-sized cities, but some of them are primarily administrative centers rather than commerce oriented (Braunerhjelm, 2008). The new institutions are located in cities with less than 100,000 inhabitants, and typically around 50,000 inhabitants.

${ }^{18}$ We thank Serguey Braguinsky for extracting the U.S. data. The extract was approved for release by NSF. The data covers biological, agricultural, and environmental life sciences; computer and information sciences; mathematics and statistics; the physical sciences; psychology; the social sciences; engineering; and health fields. The varying periodicity between surveys makes it somewhat complicated to compute an average rate of entrepreneurship. We have three sets of comparable pre-entrepreneurship employment years: 1997, 1999 and 2003 and three follow-up years: 1999, 2003, and 2006.

${ }^{19}$ See www.oecd.org/newsroom/taxrevenuesrisingslowlyacrosstheoecd.htm.

${ }^{20}$ For details, see Alstadsaeter and Jacob (2012).

${ }^{21}$ If not stated differently, figures refer to 2012.

${ }^{22}$ Corporations with four or fewer shareholders who control at least 50 percent of the shares, and where all active shareholders in sum count as one shareholder. In this paper we study this group and sole proprietorships.

${ }^{23}$ In Natural Science we include natural sciences, mathematics, computer science, and agricultural science.

${ }^{24}$ Dividends and capital gains only for closely held corporations (firms where ownership is concentrated (> 50\%) to a maximum of four individuals.) This requirement is imposed to exclude dividends and capital gains from public stock.

25 These studies assume that an individual that leaves a job and become an employee with at least a management position (as defined by occupational codes) in a newly registered firm is an entrepreneur. We presume that employees with Ph.D. degrees leaving universities to join a newly registered firm with 10 or less employees are relatively important employees such that imposing additional occupational code constraint to define them as entrepreneurs is not necessary. We perform sensitivity analysis including and excluding these individuals in analysis and further analyze the extent to which they share profits in the new firm. 
${ }^{26}$ The more typical measure of experience; number of years since first employment, would be censored by the year 1999 and thus measured more imprecisely.

${ }^{27}$ Note that the result regarding R\&D intensity is opposite to that estimated from survey data in Wahlbin and Wigren (2007). We also ran a conditional logit model to examine whether changes in covariates explained the probability of becoming an entrepreneur while controlling for individual fixed effects. These also showed a significant effect for university R\&D intensity, while the effect of local market dynamism became insignificant. Results are available on request from the corresponding author. 
Table 1. Definitions of Variables, Mean and Standard Deviations.

\begin{tabular}{|c|c|c|c|c|}
\hline Variable & Description & Mean (S.D.) & & t-test \\
\hline & & Entrepreneur & $\begin{array}{l}\text { Never } \\
\text { entrepreneur }\end{array}$ & \\
\hline Total income $e_{i, t}$ & $\begin{array}{l}\text { Sum of wages, business income, } \\
\text { dividends, and capital gains }\end{array}$ & $\begin{array}{l}418247 \\
(518,466)\end{array}$ & $\begin{array}{l}443,994 \\
(346,775)\end{array}$ & $-3.75^{* *}$ \\
\hline Entrepreneur $_{i, t}$ & $=1$ if active as entrepreneur, else 0 & $\begin{array}{l}.395 \\
(.489)\end{array}$ & & \\
\hline Medicine $_{i}$ & $=1$ if Ph.D. in medical science, else 0 & $\begin{array}{l}.225 \\
(.417)\end{array}$ & $\begin{array}{l}.275 \\
(.444)\end{array}$ & $-5.44 * *$ \\
\hline Engineering $i$ & $=1$ if Ph.D. in engineering, else 0 & $\begin{array}{l}.411 \\
(.492)\end{array}$ & $\begin{array}{l}.329 \\
(.463)\end{array}$ & $10.9 * *$ \\
\hline Natural Science $_{i}$ & $=1$ if Ph.D. in natural sciences, else 0 & $\begin{array}{l}.364 \\
(.480)\end{array}$ & $\begin{array}{l}.424 \\
(.490)\end{array}$ & $-4.32 * *$ \\
\hline Foreign born $_{i}$ & $=1$ if born outside Sweden, else 0 & $\begin{array}{l}.150 \\
(.357)\end{array}$ & $\begin{array}{l}.198 \\
(.398)\end{array}$ & $-6.20 * *$ \\
\hline Male $_{\mathrm{i}}$ & $=1$ if male, else 0 & $\begin{array}{l}.750 \\
(.433)\end{array}$ & $\begin{array}{l}.695 \\
(.460)\end{array}$ & $6.14^{* *}$ \\
\hline Age $_{i, t}$ & Age of individual & $\begin{array}{l}43,5 \\
(9.46)\end{array}$ & $\begin{array}{l}44.0 \\
(9.46)\end{array}$ & $-2.67 * *$ \\
\hline $\mathrm{GPA}_{\mathrm{i}}$ & $\begin{array}{l}\text { Grade point average from secondary } \\
\text { education }\end{array}$ & $\begin{array}{l}15.7 \\
(2.23)\end{array}$ & $\begin{array}{l}16.1 \\
(2.23)\end{array}$ & $-6.38 * *$ \\
\hline Years Experience $e_{i, t}$ & Number of years since obtaining PhD & $\begin{array}{l}8.20 \\
(6.89)\end{array}$ & $\begin{array}{l}9.69 \\
(8.50)\end{array}$ & $-9.01 * *$ \\
\hline $\begin{array}{l}\text { Non-academic } \\
\text { experience }_{i}\end{array}$ & $\begin{array}{l}=1 \text { if worked outside academia before } \\
\text { reentering university, else } 0\end{array}$ & $\begin{array}{l}.388 \\
(.487)\end{array}$ & $\begin{array}{l}.152 \\
(.356)\end{array}$ & $33.3^{* *}$ \\
\hline Manufacturing & $\begin{array}{l}=1 \text { if the new firm operates in } \\
\text { manufacturing industry, else } 0\end{array}$ & $\begin{array}{l}.095 \\
(.293)\end{array}$ & & \\
\hline High end service $_{i}$ & $\begin{array}{l}=1 \text { if the new firm operates in high- } \\
\text { end service sector, else } 0\end{array}$ & $\begin{array}{l}.633 \\
(.482)\end{array}$ & & \\
\hline Low end service ${ }_{i}$ & $\begin{array}{l}=1 \text { if the new firm operates in low-end } \\
\text { service sector, else } 0\end{array}$ & $\begin{array}{l}.272 \\
(.445)\end{array}$ & & \\
\hline Sole proprietor $r_{i}$ & $\begin{array}{l}=1 \text { if the new firm is a sole } \\
\text { proprietorship, else } 0\end{array}$ & $\begin{array}{l}.094 \\
(.292)\end{array}$ & & \\
\hline $\begin{array}{l}\text { Ownership not } \\
\text { registred }\end{array}$ & $\begin{array}{l}=1 \text { if the academic's ownership in the } \\
\text { new firm cannot be established }\end{array}$ & $\begin{array}{l}.320 \\
(.467)\end{array}$ & & \\
\hline Local market size $\mathrm{i}_{\mathrm{i}, \mathrm{t}}$ & $\begin{array}{l}\text { No. individuals with tertiary education } \\
\text { in the labor market region }\end{array}$ & $\begin{array}{l}645 \\
(200)\end{array}$ & $\begin{array}{l}658 \\
(.198)\end{array}$ & $-3.15^{* *}$ \\
\hline $\begin{array}{l}\text { Local market } \\
\text { dynamism }_{i, t}\end{array}$ & $\begin{array}{l}\text { No. entry/ no. current firms in the } \\
\text { labor market region }\end{array}$ & $\begin{array}{l}.121 \\
(.051)\end{array}$ & $\begin{array}{l}.126 \\
(.051)\end{array}$ & $-5.29 * *$ \\
\hline $\begin{array}{l}\text { University } \quad R \& D \\
\text { intensity }\end{array}$ & $\begin{array}{l}\text { Research funding per FTE at university } \\
\text { where the individual is employed } \\
\text { (million SEK) }\end{array}$ & $\begin{array}{l}1.26 \\
(.665)\end{array}$ & $\begin{array}{l}1.31 \\
(.667)\end{array}$ & -3.33 \\
\hline
\end{tabular}

Legend: **significant at $1 \%$ level or better, * significant at $5 \%$ level.

Notes. 1) 2,720 year observations on 478 individuals moving from employment at a university to entrepreneurship after 1999 and before 2009. 2): 85,020 year observations on 18,661 individuals staying within academia for all observed years. Data are individual-year observations, varying across individuals $i$ and years $t$. Sector dummies and startup firm characteristics apply only to those becoming entrepreneurs. Yearly observations for individuals who exit entrepreneurship are excluded from analysis. Future dividends and stock sales, if emanating from the firm held during entrepreneurship, are exempt from this rule. Data on dividends and sales extend to 2010. 
Table 2. Earnings for Academics Prior to and After Becoming Entrepreneurs.

\begin{tabular}{|l|l|l|l|}
\hline Variable & $\begin{array}{l}\text { Prior to } \\
\text { becoming } \\
\text { entrepreneu } \\
r\end{array}$ & $\begin{array}{l}\text { After } \\
\text { becoming } \\
\text { entrepreneu } \\
r\end{array}$ & t-value \\
\hline Total earnings & $\begin{array}{l}397,307 \\
(223,126)\end{array}$ & $\begin{array}{l}450,341 \\
(776,616)\end{array}$ & $-2.61^{* *}$ \\
\hline $\begin{array}{l}\text { Regular earnings } \\
\text { (wages } \\
\text { income) }\end{array}$ & $\begin{array}{l}390,131 \\
(205,735)\end{array}$ & $\begin{array}{l}380,744 \\
(781,291)\end{array}$ & -0.46 \\
\hline \multicolumn{1}{|c|}{ business } & $\begin{array}{l}\text { (73,028 } \\
(845,879)\end{array}$ & $-2.95^{* *}$ \\
\hline Dividends & $\begin{array}{l}6,433 \\
(95,790)\end{array}$ & $\begin{array}{l}4,753 \\
(109,240)\end{array}$ & 1.34 \\
\hline Capital gains & $\begin{array}{l}743 \\
(19,541)\end{array}$ & 1,074 & \\
\hline $\begin{array}{l}\text { Number of } \\
\text { observations }\end{array}$ & 1,646 & & \\
\hline
\end{tabular}

Note: In 2008 Swedish kronor. 1 Swedish krona varied between 0.12 and 0.17 \$U.S. in 2008. Values are annual, except for capital gains which are computed as described in Table 1 . Legend: **significant at $1 \%$ level or better. 
Table 3. Difference-in-difference Earnings Regressions for those Becoming Entrepreneurs.

\begin{tabular}{|c|c|c|c|c|}
\hline & Total income & Total income & In(Total income) & In(Total income) \\
\hline Entrepreneur $_{i, t}$ & $\begin{array}{l}26,070 \\
(28,673)\end{array}$ & $\begin{array}{l}-263,670 \\
(141,481)\end{array}$ & $\begin{array}{l}-.256^{*} \\
(.112)\end{array}$ & $\begin{array}{l}.641 \\
(.908)\end{array}$ \\
\hline Ent*Medicine $_{i}$ & & $\begin{array}{l}66,971 \\
(67,737)\end{array}$ & & $\begin{array}{l}.125 \\
(246)\end{array}$ \\
\hline Ent*Engineering $_{i}$ & & $\begin{array}{l}-3708 \\
(24,877)\end{array}$ & & $\begin{array}{r}-.093 \\
(.204)\end{array}$ \\
\hline Ent*Foreign born $_{i}$ & & $\begin{array}{l}-13,539 \\
(40,088)\end{array}$ & & $\begin{array}{l}-1.00 * * \\
(.321)\end{array}$ \\
\hline Ent*Male $_{\mathrm{i}}$ & & $\begin{array}{l}15,939 \\
(30,145)\end{array}$ & & $\begin{array}{l}.063 \\
(.242) \\
\end{array}$ \\
\hline Ent*Age & & $\begin{array}{l}2,506 \\
(2,320)\end{array}$ & & $\begin{array}{l}-.003 \\
(.016)\end{array}$ \\
\hline Ent $^{*} \mathrm{GPA}_{\mathrm{i}}$ & & $\begin{array}{l}5,339 \\
(3,387)\end{array}$ & & $\begin{array}{l}-.013 \\
(.014)\end{array}$ \\
\hline Ent $^{*}$ Years Experience $e_{i, t}$ & & $\begin{array}{l}-7.79 \\
(2,733)\end{array}$ & & $\begin{array}{l}.003 \\
(.018)\end{array}$ \\
\hline $\begin{array}{l}\text { Ent*Non-academic }^{*} \text { Nonce }_{i} \\
\text { experiencin }\end{array}$ & & $\begin{array}{l}6,143 \\
(38,585)\end{array}$ & & $\begin{array}{l}.159 \\
(.180)\end{array}$ \\
\hline Ent*Manufacturing $_{i}$ & & $\begin{array}{l}11,192 \\
(45,624)\end{array}$ & & $\begin{array}{l}.301 \\
(.282)\end{array}$ \\
\hline Ent*High end service $_{i}$ & & $\begin{array}{l}-36,537 \\
(29,707)\end{array}$ & & $\begin{array}{l}.278 \\
(.232)\end{array}$ \\
\hline Ent*Sole prop $_{. i}$ & & $\begin{array}{l}-239,841^{* *} \\
(34,665)\end{array}$ & & $\begin{array}{l}-3.22 * * \\
(.612)\end{array}$ \\
\hline $\begin{array}{l}\text { Ent*Ownership not } \\
\text { registred }_{i}\end{array}$ & & $\begin{array}{l}-24,136 \\
(29,321)\end{array}$ & & $\begin{array}{l}.305^{*} \\
(.134)\end{array}$ \\
\hline Ent*Local market size $_{\mathrm{i}, \mathrm{t}}$ & & $\begin{array}{l}73 \\
(65)\end{array}$ & & $\begin{array}{l}.001 \\
(.001)\end{array}$ \\
\hline $\begin{array}{ll}\text { Ent* }{ }^{*} \text { ocal } & \text { market } \\
\text { dynamism }_{i, t} & \end{array}$ & & $\begin{array}{l}728,182 \\
(457,026)\end{array}$ & & $\begin{array}{l}2.12 \\
(1.79)\end{array}$ \\
\hline $\begin{array}{l}\text { Ent*University } \quad R \& D \\
\text { intensity }{ }_{i, t}\end{array}$ & & $\begin{array}{l}6,918 \\
(221,934)\end{array}$ & & $\begin{array}{l}-.089 \\
(.124)\end{array}$ \\
\hline
\end{tabular}

Difference-in-difference estimate of the effect on total income of switching from employment at a university to entrepreneurship. Year dummies included in all models. Legend: ${ }^{* *}$ significant at $1 \%$ level or better, ${ }^{*}$ significant at $5 \%$ level. 
Table 4. Maximum Likelihood Logit Regressions Predicting the Probability of an Academic Becoming an Entrepreneur.

\begin{tabular}{|c|c|c|}
\hline & $\begin{array}{c}\text { Panel logit } \\
\text { random effects }\end{array}$ & $\begin{array}{c}\text { Panel logit } \\
\text { random effects }\end{array}$ \\
\hline Medicine $_{i}$ & $\begin{array}{l}-.152 \\
(.157) \\
\end{array}$ & $\begin{array}{c}.100 \\
(.159) \\
\end{array}$ \\
\hline Engineering $_{i}$ & $\begin{array}{l}.357^{* *} \\
(.128) \\
\end{array}$ & $\begin{array}{l}.481^{* *} \\
(.129) \\
\end{array}$ \\
\hline Foreign born $_{i}$ & $\begin{array}{l}-.342^{*} \\
(.159)\end{array}$ & $\begin{array}{c}-.370 * \\
(.159)\end{array}$ \\
\hline Male $_{i}$ & $\begin{array}{l}.270 * \\
(.132) \\
\end{array}$ & $\begin{array}{l}.487^{* *} \\
(.137) \\
\end{array}$ \\
\hline $\operatorname{Age}_{i, t}$ & $\begin{array}{l}-.010 \\
(.010) \\
\end{array}$ & $\begin{array}{l}-.001 \\
(.010)\end{array}$ \\
\hline $\mathrm{GPA}_{\mathrm{i}}$ & $\begin{array}{c}-.077^{* *} \\
(.027)\end{array}$ & $\begin{array}{l}-.055 \\
(.028)\end{array}$ \\
\hline Years Experience $_{i, t}$ & $\begin{array}{c}-.054 * * \\
(.012)\end{array}$ & $\begin{array}{c}-.034 * * \\
(.012)\end{array}$ \\
\hline Non-academic experience $_{i}$ & $\begin{array}{l}1.49 * * \\
(.115) \\
\end{array}$ & $\begin{array}{l}1.64^{* *} \\
(.115)\end{array}$ \\
\hline Local market size $\mathrm{e}_{\mathrm{i}, \mathrm{t}}$ & $\begin{array}{c}2.3 e-04 \\
(3.9 e-04)\end{array}$ & $\begin{array}{c}2.2 e-04 \\
(3.9 e-04)\end{array}$ \\
\hline Local market dynamism ${ }_{i, t}$ & $\begin{array}{c}-8.98^{*} \\
(4.24)\end{array}$ & $\begin{array}{c}-9.32 * \\
(4.26)\end{array}$ \\
\hline University R\&D intensity ${ }_{i, t}$ & $\begin{array}{l}.280 * * \\
(.096) \\
\end{array}$ & $\begin{array}{l}.276 * * \\
(.096) \\
\end{array}$ \\
\hline Total Income $e_{i, t-1}$ & & $\begin{array}{c}-2.7 e-06^{* *} \\
(3.9 e-07)\end{array}$ \\
\hline 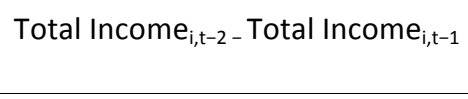 & & $\begin{array}{l}-4.8 e-07 \\
(2.6 e-07)\end{array}$ \\
\hline
\end{tabular}

Selection into entrepreneurship among university-employed Ph.D.'s. Legend: **significant at $1 \%$ level or better, * significant at $5 \%$ level. Year dummies included. 
Appendix: Tax rates and Marginal Tax Rates by type of Income, 2000-2012.

\begin{tabular}{|c|c|c|c|c|c|c|c|c|c|}
\hline \multirow[t]{4}{*}{ Year } & \multicolumn{2}{|l|}{ Labor income } & \multicolumn{6}{|c|}{ Capital income } & \multirow{4}{*}{$\begin{array}{l}\text { Corporate } \\
\text { Income }\end{array}$} \\
\hline & \multirow{3}{*}{$\begin{array}{l}\text { Without soc. } \\
\text { security } \\
\text { contribution }\end{array}$} & \multirow{3}{*}{$\begin{array}{l}\text { With soc. } \\
\text { security }\end{array}$} & \multirow[t]{3}{*}{ Interest } & \multirow{3}{*}{$\begin{array}{l}\text { Capital } \\
\text { gains, } \\
\text { not 3:12 }\end{array}$} & \multicolumn{3}{|c|}{ Dividend } & \multirow{3}{*}{$\begin{array}{l}\text { CHC 3:12 } \\
\text { Exceeding } \\
\text { allowance }\end{array}$} & \\
\hline & & & & & \multirow{2}{*}{$\begin{array}{l}\text { Listed } \\
\text { shares }\end{array}$} & \multirow[t]{2}{*}{ Unlisted } & \multirow{2}{*}{$\begin{array}{l}\mathrm{CHC} \\
3: 12\end{array}$} & & \\
\hline & & & & & & & & & \\
\hline 2000 & $30,4-55,4$ & $\begin{array}{l}47,6- \\
66,4\end{array}$ & 30 & 30 & 30 & 30 & 30 & $30,4-55,4$ & 28 \\
\hline 2001 & $30,5-55,5$ & $\begin{array}{l}47,7- \\
66,5\end{array}$ & 30 & 30 & 30 & 30 & 30 & $30,5-55,5$ & 28 \\
\hline 2002 & $30,5-55,5$ & $\begin{array}{l}47,7- \\
66,5\end{array}$ & 30 & 30 & 30 & 30 & 30 & $30,5-55,5$ & 28 \\
\hline 2003 & $31,2-56,2$ & $\begin{array}{l}48,2- \\
67,0\end{array}$ & 30 & 30 & 30 & 30 & 30 & $31,2-56,2$ & 28 \\
\hline 2004 & $31,5-56,5$ & $\begin{array}{l}48,4- \\
67,2\end{array}$ & 30 & 30 & 30 & 30 & 30 & $31,5-56,5$ & 28 \\
\hline 2005 & $31,6-56,6$ & $\begin{array}{l}48,4- \\
67,2\end{array}$ & 30 & 30 & 30 & 30 & 30 & $31,6-56,6$ & 28 \\
\hline 2006 & $31,6-56,6$ & $\begin{array}{l}48,3- \\
67,2\end{array}$ & 30 & 30 & 30 & 25 & 20 & $31,6-56,6$ & 28 \\
\hline 2007 & $31,6-56,6$ & $\begin{array}{l}48,3- \\
67,2\end{array}$ & 30 & 30 & 30 & 25 & 20 & $31,6-56,6$ & 28 \\
\hline 2008 & $31,4-56,4$ & $\begin{array}{l}48,2- \\
67,1\end{array}$ & 30 & 30 & 30 & 25 & 20 & $31,4-56,4$ & 28 \\
\hline 2009 & $31,5-56,5$ & $\begin{array}{l}47,9- \\
66,9\end{array}$ & 30 & 30 & 30 & 25 & 20 & $31,5-56,5$ & 26,3 \\
\hline 2010 & $31,6-56,6$ & $\begin{array}{l}47,9- \\
67,0\end{array}$ & 30 & 30 & 30 & 25 & 20 & $31,6-56,6$ & 26,3 \\
\hline 2011 & $31,6-56,6$ & $\begin{array}{l}47,9- \\
67,0\end{array}$ & 30 & 30 & 30 & 25 & 20 & $31,6-56,6$ & 26,3 \\
\hline 2012 & $31,6-56,6$ & $\begin{array}{l}47,9- \\
67,0\end{array}$ & 30 & 30 & 30 & 25 & 20 & $31,6-56,6$ & 26,3 \\
\hline
\end{tabular}

Source: Alstadsæter and Jacob (2012). 
Figure 1. Kernel Density Estimate, Total Income.

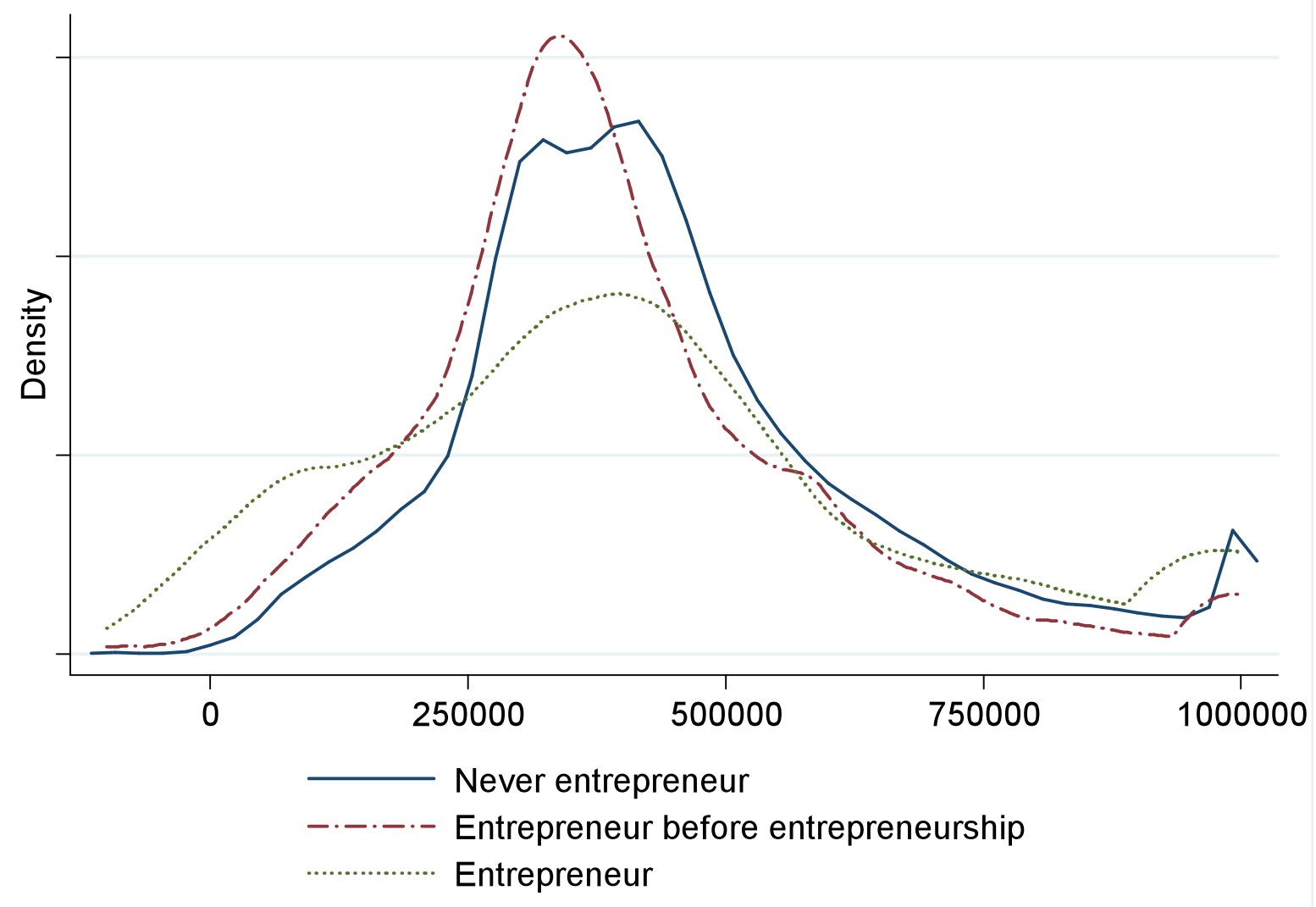

Note: The kernel used was Epanechnikov, with bandwidth $1.5^{*} 10^{4}$ 
Figure 2. Business Survival for Academic Entrepreneurs.

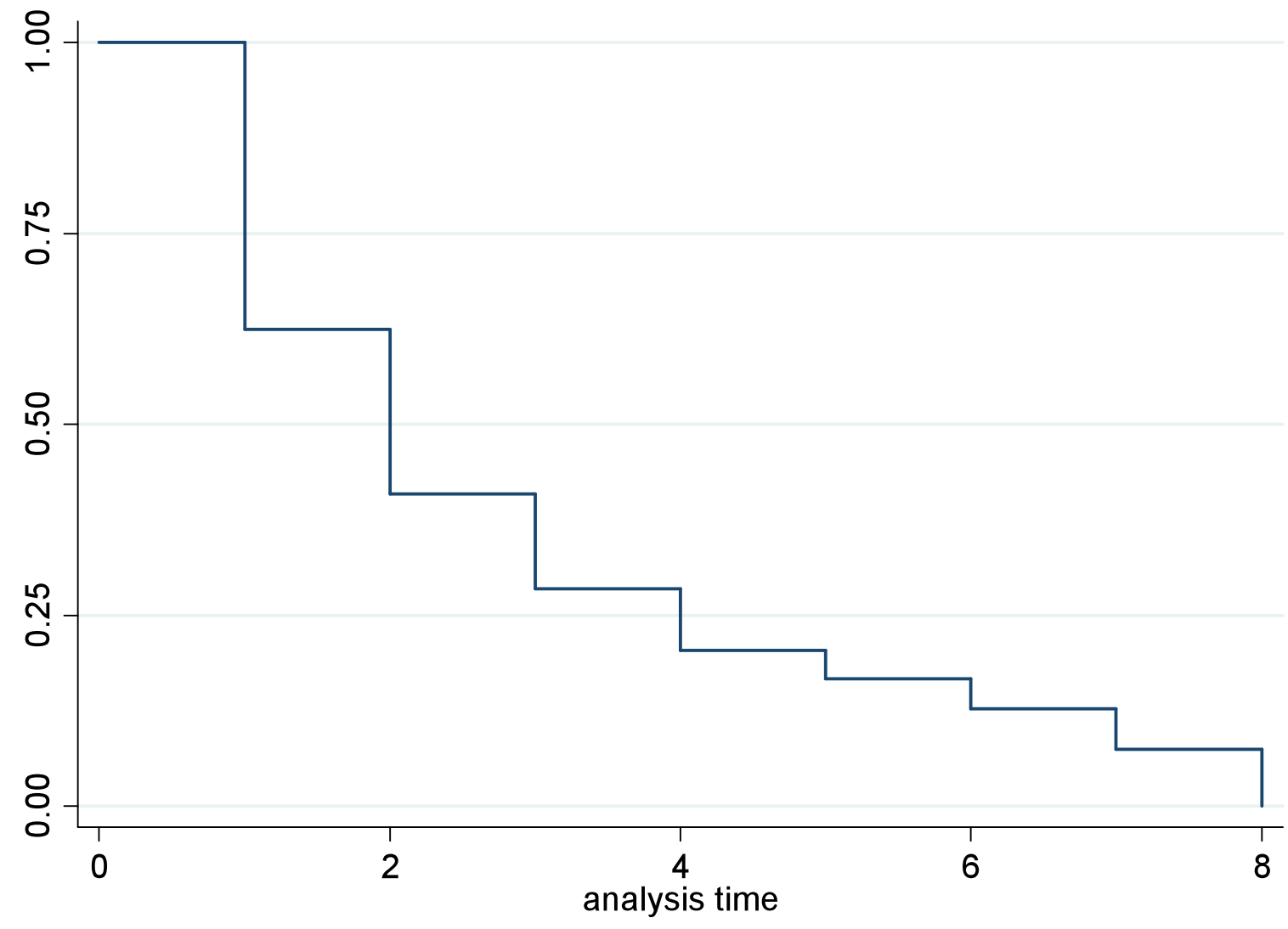

Note: The survival graph was estimated using Kaplan-Meier, which corrects for right censoring. 
Figure 3. Total Income Across Years.

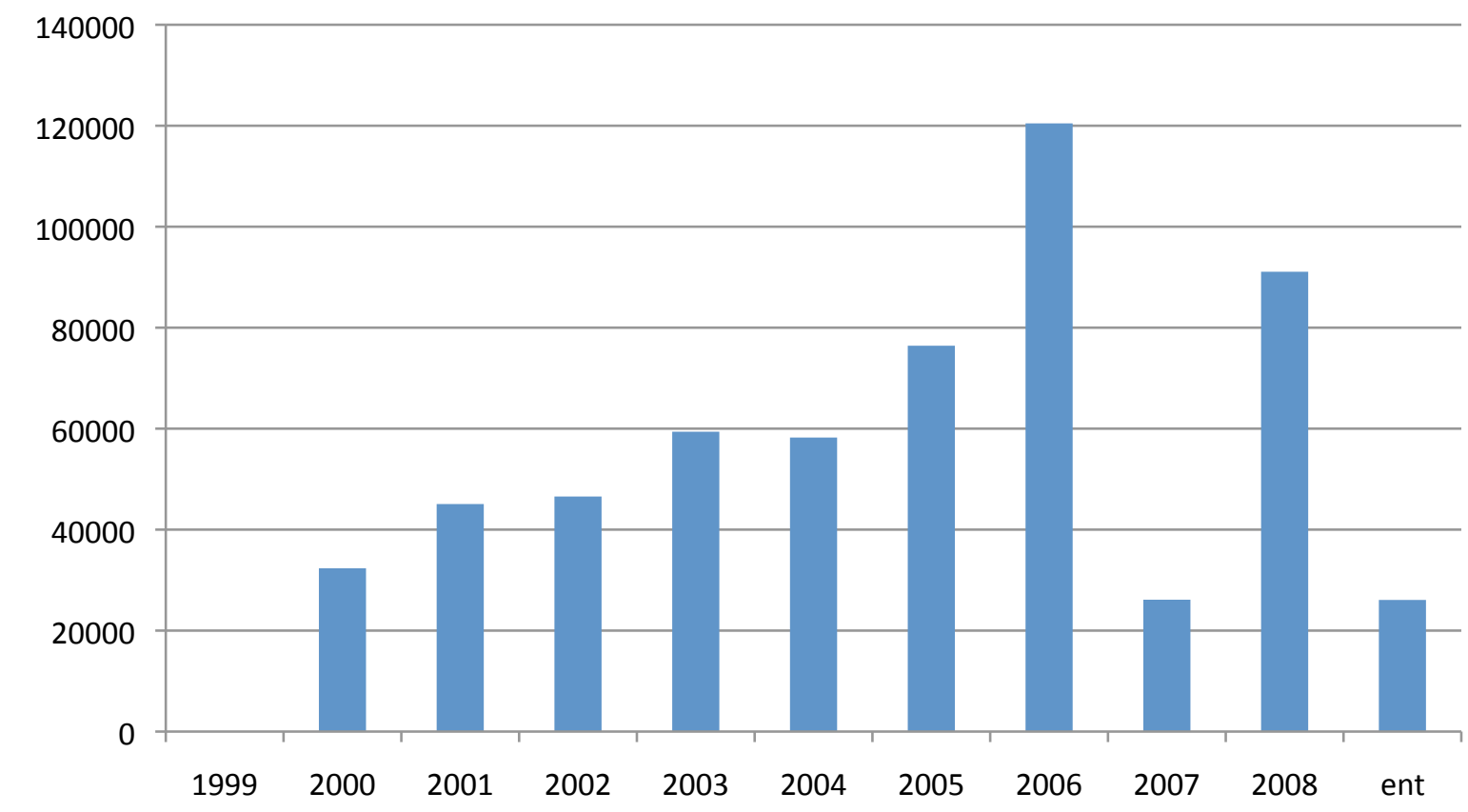

Notes: Bars represent dummy variables estimated as in equation (1). 1999 represents the intercept. The final right-hand bar is the estimated return to entrepreneurship. All year dummies except that for 2007 are statistically significantly different from 1999. Values are the sum of wages, business income, dividends and capital gains in 2008 SEK. 1 Swedish krona varied between USD 0.12 and 0.17 in 2008 . 
Figure 4. Kernel Density Estimate, Logged Value of Total Income

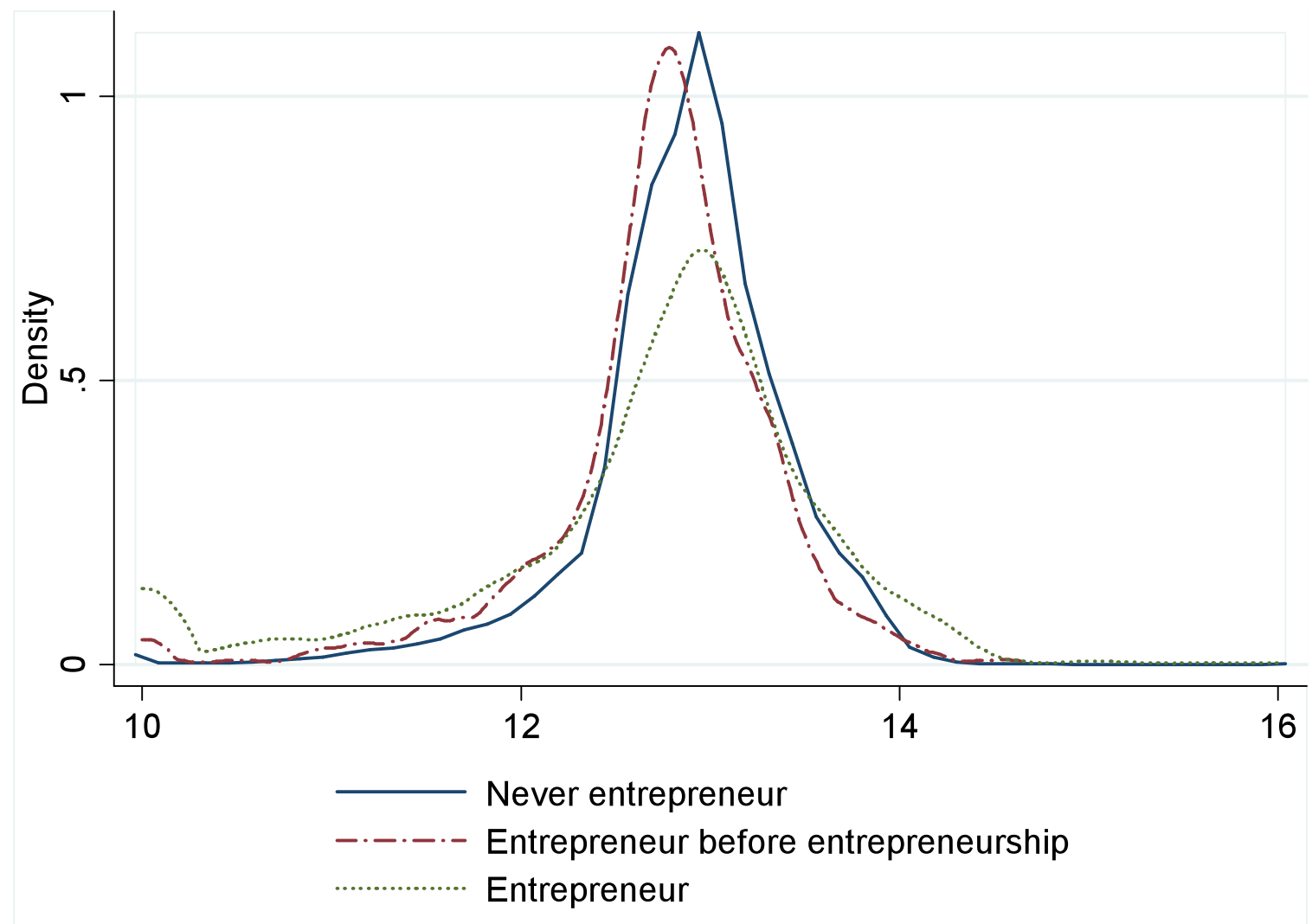

Note: The kernel used was Epanechnikov, with bandwidth 0.037. 


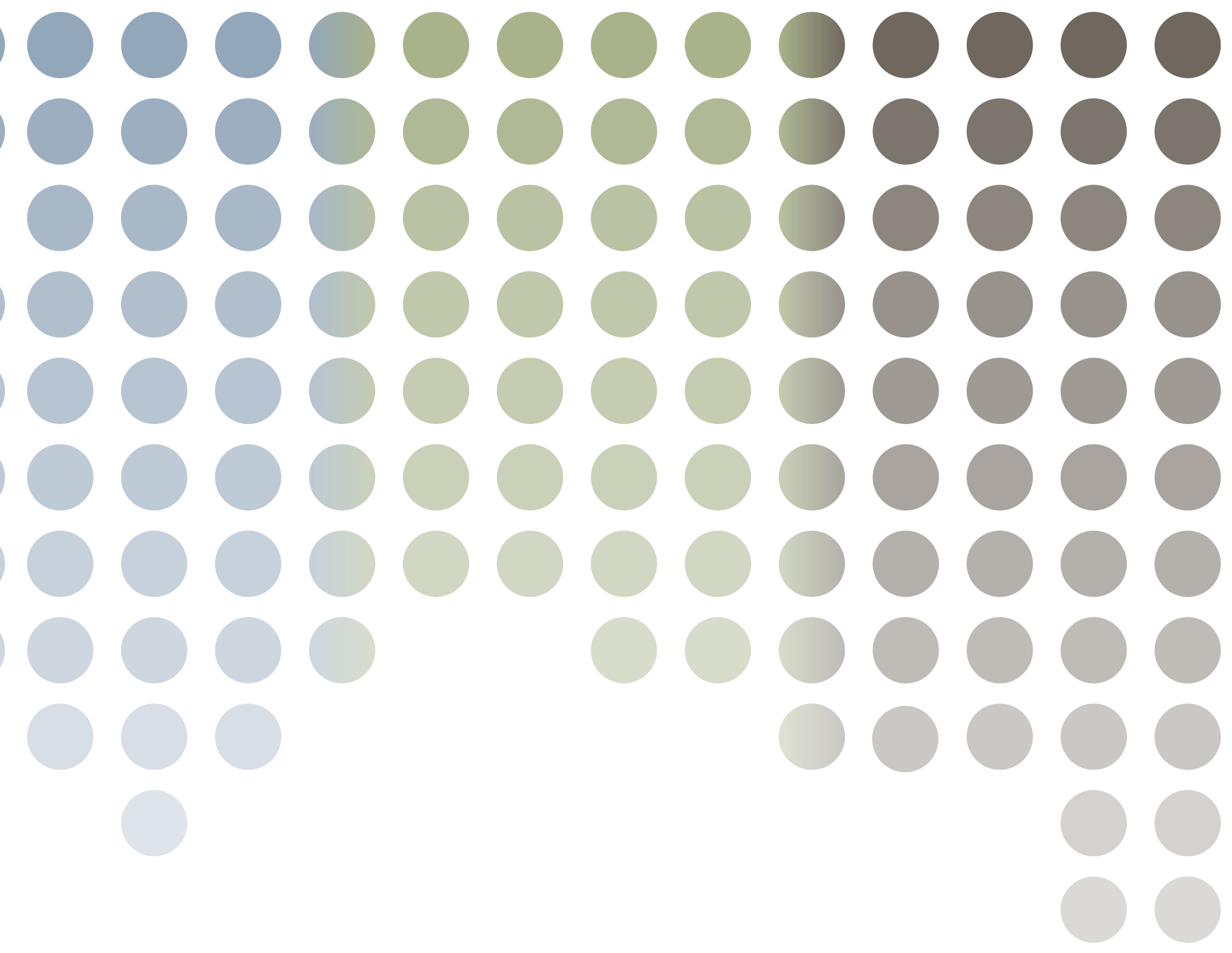

